\title{
Nanoenhanced Materials for Reclamation of Mine Lands and Other Degraded Soils: A Review
}

\author{
Ruiqiang Liu and Rattan Lal \\ Carbon Management \& Sequestration Center, School of Environment and Natural Resources, Ohio State University, \\ 210 Kottman Hall, 2021 Coffey Road, Columbus, OH 43210, USA \\ Correspondence should be addressed to Ruiqiang Liu, liu.603@osu.edu
}

Received 7 March 2012; Revised 14 May 2012; Accepted 14 May 2012

Academic Editor: William W. Yu

Copyright ( 92012 R. Liu and R. Lal. This is an open access article distributed under the Creative Commons Attribution License, which permits unrestricted use, distribution, and reproduction in any medium, provided the original work is properly cited.

Successful mine soil reclamation facilitates ecosystem recovery, minimizes adverse environmental impacts, creates additional lands for agricultural or forestry uses, and enhances the carbon $(\mathrm{C})$ sequestration. Nanoparticles with extremely high reactivity and deliverability can be applied as amendments to improve soil quality, mitigate soil contaminations, ensure safe land-application of the conventional amendment materials (e.g., manures and biosolids), and enhance soil erosion control. However, there is no report on using nanoenhanced materials for mine soil reclamation. Through reviewing the up-to-date research results on using environment-friendly nanoparticles for agricultural soil quality improvement and for contaminated soil remediation, this paper synthesizes that these nanomaterials with high potentials for mine soil reclamation include zeolites, zero-valent iron nanoparticles, iron oxide nanoparticles, phosphate-based nanoparticles, iron sulfide nanoparticles and C nanotubes. Transport of these particles in the environment and their possible ecotoxicological effects are also discussed. Additionally, this article proposes a practical and economical approach to applying nanotechnology for mine soil reclamation: adding small amounts of nanoparticles to the conventional soil amendment materials and then applying the mixtures for soil quality improvements. Hence the cost of using nanoparticles is reduced and the benefits of both nanoparticles and the conventional amendment materials are harnessed.

\section{Introduction}

Ever since the commencement of industrial-scale mining of coal and other minerals, drastic environmental impacts have been recorded arising from both the mined lands and from the wastes left behind at the surface $[1,2]$. The local landscape and the soil quality are among the most severely disturbed environmental components by the mining processes through directly stripping the vegetation and soil layers (open-pit mining) and/or through depositing the ores and mining wastes on the soils [3]. Dramatic alterations of the geological environment of the coal/ores and the mining wastes significantly reduce the chemical stability of the minerals, resulting in the release of the environmental disruptive chemicals into the soils and creating the "mine soils." Typical mine soils often refer to the antecedent or original soils which are affected and degraded by the acid drainage and mining wastes. Practically, this type of soils also include the exposed parent materials due to accelerated soil erosion and/or the top soil removal for open pit mining, and the deposition of mining solid wastes. Although the properties vary from location to location depending on the local geochemistry, a mine soil is usually acidic, heavy-metal laden, nutrient depleted, highly compacted, and not favorable to plant growth [4].

The strategy for mine soil reclamation is to minimize the environmental impacts of mining by restoring the mine soils and the local ecosystems to the antecedent levels. An adequate reclamation of mine soils not only benefits the local environment but also can contribute to improving the global environment through carbon (C) storage in biomass and in the soils, and thus off-setting the increase of $\mathrm{CO}_{2}$ emissions from industrial activities. The depleted and drastically disturbed mine soils have a larger potential of $\mathrm{C}$ storage over agricultural soils due to the fact that intensively cultivated soils contain relatively high soil organic matter (SOM) and further increasing the $\mathrm{C}$ sink capacity is difficult. In contrast, mine soils usually contain low soil organic C (SOC) and thus possess high $\mathrm{C}$ storage potentials. Taking full advantages of 
the available $\mathrm{C}$ sink capacity by growing vegetation at the abandoned mining sites would increase the atmospheric $\mathrm{CO}_{2}$ adsorption and enhance the terrestrial $\mathrm{C}$ sequestration [5-7].

Reclamation of mine soils for $\mathrm{C}$ sequestration requires high quality of remediation techniques and treatments. It is not enough just to protect against acid mine drainage (AMD) and heavy metals from contaminating the ground and surface waters. The mine soils must be reclaimed in situ so that the grasses, crops, or trees could grow sustainably with limited management. On a long run, a quick establishment of the vegetation and enhancing microbial activities in a mine soil can improve soil quality by accentuating phytoremediation of the contaminants, decreasing soil erosion, and enhancing concentrations of SOM and plant nutrients.

1.1. Mine Soil Quality and Amendment Materials. Harnessing an effective $\mathrm{CO}_{2}$ sink of a mine soil site requires establishment and maintenance of a healthy forest or other vegetation cover for a time scale of at least 25 years. Soils with high quality are indispensable to support the vegetation that can thrive and sustain itself. However, mine soils, especially the gob piles or mining rock wastes, usually have poor soil quality such as low SOM content, low fertility, micronutrient imbalance or toxicity, low $\mathrm{N}$ and $\mathrm{P}$ availability, soil compaction caused by the grading operations, shallow soil depth, low moisture holding capacity, high electrical conductivity, high heavy metal contents, and extreme $\mathrm{pH}$, which all adversely affect vegetation establishments and SOC sequestration [5]. Therefore, soil amendments and proper management are needed in order to improve the soil physical, chemical, and biological properties at a disturbed site for establishing vegetation and making it an effective atmospheric $\mathrm{CO}_{2}$ sink. Several natural minerals and agricultural, industrial and municipal wastes have been tried for these purposes as soil amendments. For example, manures $[8,9]$, composts [10], biosolids [9, 11, 12], and paper mill sludge [9] have been successfully applied to increase the SOM content in the mine soils. Limestones, zeolites [13], and coal combustion byproducts [14-16] (e.g., fly ash, bottom ash, and flue gas desulfurization (FGD) gypsum) have also been intensively researched in reducing mine soil acidity and decreasing the heavy metal toxicity and uptake by plants. A range of various commercial $\mathrm{N}, \mathrm{P}$, and $\mathrm{K}$ fertilizers have been used to provide adequate nutrients for the vegetation establishment at mining sites as well $[8,12,17]$. The land applications of these conventional amendment materials are also encouraged by the increasing demands on disposal and reuse of these industrial by-products and community wastes at low cost. However, various levels of heavy metals (e.g., $\mathrm{Hg}, \mathrm{Cd}, \mathrm{Cr}$, and $\mathrm{Pb}$ ) and other toxic elements (B, As, Se, and Mo) often occur in coal combustion by-products [18]. Nuisance odors, the potential of pathogen transmission, and presence of toxic and persistent organic chemicals and metals in biosolids have for the most part limited the use of land applications [19]. A survey study [20] on 9 different biosolids produced by municipal wastewater treatment plants in 7 USA states indicated that some biosolids were highly enriched in organic wastewater contaminants (OWCs), suggesting the land application of the solids might become a potential nonpoint source of OWCs into the environment. The OWCs included pharmaceuticals, hormones, detergent metabolites, fragrances, plasticizers, and pesticides. Therefore, new types of effective and environmentally safe soil amendment materials are urgently needed for mine soil reclamation.

1.2. Using Nanoenhanced Materials as Soil Amendments. Nanotechnology is an advanced modern approach. It provides new types of materials which offer the unique and important solutions to the limitations of other conventional materials and have numerous applications [21]. Nanomaterials and nanostructures have nanoscaled dimensions that range from 1 to $100 \mathrm{~nm}$ and often exhibit novel and significantly changed physical, chemical, and biological properties as a result of their structure, larger specific surface area, and quantum effects that occur at the nanoscale [21]. Applications of nanotechnology in water treatment and purification have witnessed significant developments in recent years [2224]. However, little progress has been made regarding the application of nanoparticles to improve agricultural soil quality and to reclaim the drastically disturbed lands. Lal [25] proposed that applying nanotechnology in agricultural sector was one of the available options to increase the agricultural production, solve environmental problems, and feed the world's growing population. Hence, it is imperative to review the state of the science of nanotechnology that has potentials in mine soil reclamation and mine soil quality improvement and to explore the feasibility of using nanoenhanced materials as replacements for the conventional amendment materials in agriculture. The specific nanotechnology interested in this paper encompass those able to increase soil $\mathrm{pH}$ and fertility, improve soil physical structures, reduce mobility, availability, and toxicity of heavy metals and other environmental contaminants and those able to stabilize the soil components and abate soil erosion at a mining site. Therefore, the overall objectives of this paper are to (a) review the available literature on various environmentallyfriendly nanoenhanced materials which could be used as in situ soil amendments for mine soil reclamation; (b) briefly discuss the transport and mobility of those nanoparticles in the environment as well as their possible ecotoxicological effects (if any); (c) propose a practical approach to application of the nanomaterials in mine soil reclamation at low cost and in a more environmentally friendly fashion.

\section{Nanomaterials for Soil Reclamation and Environmental Remediation}

Reclamation of mine soils involves removing soil contaminants and enhancing soil quality and fertility. Nanotechnology is a promising approach for these purposes. Two advantages of nanomaterials over the traditional amendments for soil reclamation include the higher reactivity due to smaller particle size and higher specific surface area and the easier delivery of the small-sized particles into the porous media (soils). High reactivity leads to a high efficiency and high rate of soil reclamation, while easy delivery is advantageous for 
in situ application. These nanomaterials with large potentials for mine soil reclamation include zeolites, zero-valent iron nanoparticles, iron oxides nanoparticles, phosphate-based nanoparticles, iron sulfide nanoparticles, and $\mathrm{C}$ nanotubes. With emphasis on their functions in soil quality improvements, transport and mobility of those nanoparticles in the environment as well as their possible ecotoxicological effects are also briefly introduced in this section.

2.1. Soil Conditioner-Zeolites. Zeolites are crystalline, hydrated aluminosilicates of alkali $\left(\mathrm{Na}^{+}\right.$, or $\left.\mathrm{K}^{+}\right)$and alkaline earth cations $\left(\mathrm{Ca}^{2+}\right.$ or $\left.\mathrm{Mg}^{2+}\right)$ characterized by an ability to hydrate/dehydrate reversibly and to exchange some of their constituent cations with aqueous solutions, without a major change in structure [26]. Their unique feature is that the zeolites possess an open, three-dimensional cage-like structure and a vast network of open channels extending throughout. The channels and pores, typically 0.3 to 0.7 nanometers in diameter, impart the mineral large specific area (about $105 \mathrm{~m}^{2} \mathrm{~g}^{-1}$ ) for ion exchange and for selective capture of specific molecules (e.g., $\mathrm{H}_{2} \mathrm{O}$ ). Because of these structural features, zeolites generally have low density compared with that of other minerals. Nearly 50 natural species of zeolites have been recognized, and more than 100 species have been synthesized in the laboratory [27]. Clinoptilolite is the most abundant zeolite species in the sedimentary deposits on the earth and also the most mined zeolite minerals in the world [28]. Zeolites can occur in soils but with only less than 5\% (by weight) in content, and again clinoptilolite is the major zeolite species in soils [28]. Because of their ion exchange, adsorption, and molecular sieve properties, as well as their geographically widespread abundance, zeolite minerals have generated worldwide interest for use in a broad range of applications. In agricultural industries, zeolites have been used as soil conditioners, slow-release fertilizers, and remediation agents for contaminated soils [13]. As a soil conditioner, literatures showed that zeolite nano materials can improve the mine soil quality by increasing the water holding capacity, increasing the clay-silt fractions, improving nutrient levels, and removing toxins [13].

\subsubsection{Reducing Soil Bulk Density and Improving Soil Water} Holding Capacity. Natural zeolites have several unique physical properties that make them attractive as additives to improve soil physical properties. For example, bulk density of zeolite minerals can be as low as $0.8 \mathrm{Mg} \mathrm{m}^{-3}$ due to the porous nature [13]. In comparison, mine soils usually have coarse texture (contributing to higher water infiltration rate and lower water holding capacity) and higher bulk density (hindering root growth). Adding fine-grained zeolites $(<0.05 \mathrm{~mm})$ to mine soils can increase the effective silt and clay fractions, increase the water-holding capacity, and lower the bulk density thus benefiting the vegetation establishment. Githinji et al. [29] reported application of zeolite (0.55$0.6 \mathrm{~mm})$ at a $15 \%\left(\mathrm{v} \mathrm{v}^{-1}\right)$ rate to sand $(0.31 \mathrm{~mm})$ media decreased the bulk density from 1.67 to $1.56 \mathrm{Mg} \mathrm{m}^{-3}$ and increased the available water content by 2 times. Wehtje et al. [30] attributed the increased performance of bermudagrass (Cynodon dactylon) in zeolite soil mixtures to its increased water holding capacity relative to the unamended soils, but not to any alteration of the chemical properties by the amendments. Zeolite particle size and the application rate are important parameters in improving soil physical properties. Petrovic [31] observed through laboratory studies that the optimum particle size of clinoptilolite added to golf course sand was between 0.1 to $1 \mathrm{~mm}$ in order to maximize benefits of water infiltration, water availability, and aeration. Huang and Petrovic [32] concluded that the water available to plants increased when clinoptilolite particles decreased in size and the amendment dosage increased in a sand medium. They observed that plant-available water in sand amended with 5 and $10 \%\left(\mathrm{~g} \mathrm{~g}^{-1}\right)$ clinoptilolite with a particle size of $>1 \mathrm{~mm}$ was near $6 \mathrm{~g} \mathrm{~kg}^{-1}$; whereas plant-available water in the same medium amended with 5 and $10 \%\left(\mathrm{~g} \mathrm{~g}^{-1}\right)$ of $<0.047 \mathrm{~mm}$ clinoptilolite was approximately 10 and $17 \mathrm{~g} \mathrm{~kg}^{-1}$, respectively. Huang and Petrovic [33] also reported that sand-based putting green turf could benefit from a 10\% clinoptilolite amendment by increasing shoot-growth rate by $26-60 \%$. Lopez et al. [34] proposed a method to ameliorate the drought problem by adding zeolite to the soil and acting as a wicking (capillary) material to draw the water from a shallow ground water table to plant's root zone, thus reducing the dependence on precipitation or irrigation. Their pilot study showed that the grass survived in the zeolites-packed core structures, while the grass planted in the soil at the same site died. These reports show that zeolites could be an effective soil amendment to increase the water availability in mine soils and ensure the survival of the vegetation at the sites where the soils have poor soil structures, high bulk density, low water holding capacity, and the available water mainly depends on precipitation.

\subsubsection{Improving Soil $p H$ and Cation Exchange Capacity.} Mine soils are usually acidic and infertile with low cation exchange capacity (CEC), resulting in poor nutrient status for plant growth. In contrast, pure zeolite materials usually have high CEC ranging from 220 to $570 \mathrm{cmol}_{\mathrm{c}} \mathrm{kg}^{-1}$ [28]. Adding zeolites to a soil can increase the soil's overall CEC and $\mathrm{pH}$ in most cases [13], thus soil's nutrient holding capacity is enhanced. For example, Huang and Petrovic [35] applied $10 \%\left(\mathrm{~g} \mathrm{~g}^{-1}\right)$ zeolite to a sandy soil, increasing the CEC from 0.08 to $15.59 \mathrm{cmol}_{\mathrm{c}} \mathrm{kg}^{-1}$ and the $\mathrm{pH}$ from 5.4 to 6.6. After applying clinoptilolite to two types of materials (glacial till and marine clay) at a rate of $25 \%$ and $50 \%\left(\mathrm{~g} \mathrm{~g}^{-1}\right)$, the resulting $\mathrm{CEC}$ and $\mathrm{pH}$ of the mixtures increased 2.6 3.3 times and from 4.2 to 6.5 , respectively [36], reflecting the prominent effect of zeolites on raising soil CEC. It was also reported that adding $0.2 \sim 2 \%$ zeolites to soils was beneficial to crop seed germination and crop productions [37-39].

Zeolites have alkaline properties with $\mathrm{pH}$ around 8, which could increase the $\mathrm{pH}$ of acidic solution or soils. The acid neutralization property may arise from the high CEC by which zeolites exchange the solution proton $\left(\mathrm{H}^{+}\right)$with $\mathrm{Ca}^{2+}$ ion. But the acid neutralization capacity of zeolites is limited compared with agricultural liming materials. Preliminary studies conducted at the Carbon Management and Sequestration Center, the Ohio State University, USA, showed that applying zeolites at $10 \%\left(\mathrm{~g} \mathrm{~g}^{-1}\right)$ rate to mine 
soils increased the $\mathrm{pH}$ by $0.5-1$ unit [40]. Using the liming materials, $\mathrm{pH}$, however, increased by 2 to 3 units [40]. It is not known whether zeolites can suppress the acid production in mine soils resulting from the oxidation of sulfide minerals. But applying small-grained zeolites may fill the pores in the coarse-textured mine soils and reduce the oxygen diffusion to the underlying sulfide materials. Moreover, by adsorption, zeolites are able to remove gaseous molecules such as $\mathrm{H}_{2} \mathrm{~S}$ and $\mathrm{SO}_{2}$ and protect the vegetation from being harmed by these gases generated from the same sulfide-containing materials at a mine site.

There is no report using other nanomaterials for improving soil physical properties.

\subsection{Nanoenhanced Fertilizers}

2.2.1. Zeolites-Enhanced Fertilizers. Mine soils usually lack nitrogen $(\mathrm{N})$ and phosphorus $(\mathrm{P})$, and fertilizers are needed to ensure successful vegetation establishment [41]. However, applying conventional $\mathrm{N}$ fertilizers often promotes the growth of noxious weeds, suppressing the growth of crops and tree seedlings [41]. Moreover, applying too much fertilizer may increase nitrates leaching to the ground water and cause ground/surface water contaminations due to the coarse texture of the mine soils and the accelerated soil erosion. Therefore, nitrogen-loaded zeolites have been researched in order to provide a slow release of the nutrients to meet the need of crops while reducing the leaching loss of the fertilizer [13], thereby improving the fertilizer efficacy. Moreover, volatilization of gaseous $\mathrm{N}$ (e.g., as $\mathrm{NH}_{3}$ or $\mathrm{N}_{2}$ ) can also be minimized if $\mathrm{NH}_{4}{ }^{+}$-type fertilizers are exchanged onto zeolite exchange sites so that the $\mathrm{NH}_{4}{ }^{+}$ion is unavailable for conversion into gaseous phase via microbial processes [13].

Clinoptilolite is highly selective for $\mathrm{K}^{+}$and $\mathrm{NH}_{4}{ }^{+}$relative to sodium $\left(\mathrm{Na}^{+}\right)$or divalent cations such as $\mathrm{Ca}^{2+}$ and $\mathrm{Mg}^{2+}$ due to the location and density of negative charge in the structure and dimensions of interior channels [13]. Hence, $\mathrm{NH}_{4}$ - and $\mathrm{K}$-loaded zeolites are typically used as slow release fertilizers. For example, Perrin et al. [42] loaded clinoptilolite with $\mathrm{NH}_{4}{ }^{+}$by soaking the various size fractions in $1 \mathrm{M}$ $\left(\mathrm{NH}_{4}\right)_{2} \mathrm{SO}_{4}$ for 10 days (d), changing the soaking solution every 2 to $3 \mathrm{~d}$, then applied the solid to 4 -liter containers seeded with sweet corn (Zea mays). They [42] observed that the soil fertilized with $\left(\mathrm{NH}_{4}\right)_{2} \mathrm{SO}_{4}$ leached 10 to $73 \%$ of the added $\mathrm{N}$ (depending on applying $\mathrm{N}$ rate) whereas mere $<5 \%$ of the added $\mathrm{N}$ leached from the $\left(\mathrm{NH}_{4}\right)_{2} \mathrm{SO}_{4}$-zeoliteamended soil regardless of the $\mathrm{N}$ application rate and zeolite particle size. Nitrogen use efficiency (NUE) ranged from 72.0 to $95.2 \%$ in $\mathrm{NH}_{4}{ }^{+}$clinoptilolite-amended soils after $42 \mathrm{~d}$ of plant growth, compared with NUE of 29.7 to $76.3 \%$ in soils fertilized with $\left(\mathrm{NH}_{4}\right)_{2} \mathrm{SO}_{4}$ only. Moreover, Lewis et al. [43] not only observed that the $\mathrm{NH}_{4}$-loaded clinoptilolite was an efficient slow-release $\mathrm{N}$-fertilizer but also found that the amendment could prevent injury by urea to radish (Raphanus sativus) plants. Based on these evidences, Barbarick and Pirela [44] proposed that zeolites could be used effectively in agriculture to prevent leaching losses of ammoniumtype fertilizers, to reduce ammonia toxicity to plants, and to increase agronomical yields. Potassium-loaded zeolites have also been researched as a slow-release K-fertilizer [45, 46].

Phosphorus $(\mathrm{P})$ is also an important nutrient indispensable for vegetation establishment and reforestation in the reclaimed mining areas. Rock phosphates such as apatites (e.g., $\left.\mathrm{Ca}_{10}\left(\mathrm{PO}_{4}\right)_{6}(\mathrm{OH})_{2}\right)$ are commonly used sources of $\mathrm{P}$ in mine soil rehabilitation [17]. But the availability of the phosphorus from the rocks depends on the apatite dissolution in the soil. Alkaline soil $\mathrm{pH}$ often impedes the dissolution and decreases the soluble $\mathrm{P}$ amount. For example, Jacinthe and Lal [17] observed no effect of rock phosphate on the tree growth in a reclaimed mine land, probably due to the relatively high $\mathrm{pH}$ of the soil ranging from 6.5 to 8.0. Zeolites have also been used to alleviate this problem: some researchers have used a mixture of zeolite and ground apatite to increase the dissolution of the latter to provide more available $\mathrm{P}$ even at high soil pHs. The idea is to create exchange sites or a "sink" for $\mathrm{Ca}^{2+}$ in zeolites. A decrease of the $\mathrm{Ca}^{2+}$ in the soil solution by this process promotes further apatite dissolution and phosphate release. This hypothesis was first tested by Lai and Eberl [47] and confirmed by other researchers [48-50]. Lai and Eberl [47] mixed a rock phosphate with untreated and treated $\left(\mathrm{NH}_{4}{ }^{+}, \mathrm{Na}^{+}\right.$, and $\left.\mathrm{H}^{+}\right)$ zeolite at a ratio of $1: 5$ and observed that the mixture contained 5-70 times higher soluble $\mathrm{P}$ than contained in rock phosphate-only control. Using batch experiments, Allen et al. [49] showed that the higher zeolite to P rock ratio, the more $\mathrm{P}$ was released from the mixtures to the solution, further confirming the role of zeolites in P rock dissolution. These results suggested that zeolites could improve the effectiveness of rock phosphate used as $\mathrm{P}$ fertilizer in mine soil reclamation.

2.2.2. Other Nanoenhanced Fertilizers. Except for zeolitesenhanced fertilizers, there are few reports on other type of nanomaterial-related fertilizers. Concerned by the mere 30$50 \%$ efficiency of the conventional fertilizers and no other management practices to enhance the rate, Derosa et al. [51] urged to apply nanotechnology to fertilizer developments. Lal [25] also recommended that applying nanotechnology in agriculture (including fertilizer development) is one of the available options to increase the crop production and feed the world's increasing population. The observations that $\mathrm{C}$ nanotubes and zinc oxide nanoparticles are able to penetrate tomato (Lycopersicon esculentum) plant root or seed tissues indicate that new nutrient delivery systems can be developed through exploiting the nanoscale porous domains on plant surfaces [51]. Liu and Zhao [52] and Liu [53] discussed nanosized vivianite $\left(\mathrm{Fe}_{3}\left(\mathrm{PO}_{4}\right)_{2} \cdot 8 \mathrm{H}_{2} \mathrm{O}\right)$ particles $(\sim 10 \mathrm{~nm})$ and apatite $\left(\mathrm{Ca}_{5}\left(\mathrm{PO}_{4}\right)_{3} \mathrm{Cl}\right)$ particles $(<200 \mathrm{~nm})$ for heavy metal remediation. These phosphate-based nanoparticles have potentials to be used as P nanofertilizers for agricultural uses.

\subsection{Nanomaterials for Remediating the Mine Soils Contaminated with Heavy Metals and Other Toxins}

2.3.1. Zeolites. Natural and synthesized zeolites can immobilize heavy metals and radioactive nuclides in contaminated 
soils and sediments, thus reducing the risks of those toxins being released to neighboring water bodies or taken up by plants/animals. For instance, Edwards et al. [54] treated mine soils contaminated by $\mathrm{Zn}, \mathrm{Pb}, \mathrm{Cu}$, and $\mathrm{Cd}$ using synthesized zeolites at rates of $0.5-5 \%$ by weight. They observed significant reductions $(42 \%-72 \%)$ of the labile and easily-available fractions of the heavy metals after the treatments. In addition to adsorption, soil $\mathrm{pH}$ increase caused by zeolites also played a role in the metal immobilization [54]. Similar results have been reported by others [55-57] who use different leaching solutions such as $0.01 \mathrm{M} \mathrm{CaCl}_{2}$ or dilute acetate solution to evaluate the stability of the heavy metals in the soil phase. The leachable fraction of the metals by these solutions was significantly reduced after the contaminated soils were amended with 0.5 to $16 \%$ zeolites by weight [55-57]. Plants were also used as indicators to evaluate the metal toxicity and bioavailability in the zeolites-amended soils. Using rye grass (Lolium perenne L.) and alfalfa (Medicago sativa L.) as indicator plants, Haidouti [58] observed that application of zeolite at $1-5 \%\left(\mathrm{~g} \mathrm{~g}^{-1}\right)$ rates reduced plant uptake of $\mathrm{Hg}$ from a contaminated soil by up to $58 \%$ in the roots and $86 \%$ in the shoots. Chlopecka and Adriano [59] found that adding $1.5 \%\left(\mathrm{~g} \mathrm{~g}^{-1}\right)$ zeolite to a $\mathrm{Zn}$-spike soil was able to ameliorate the detrimental effect of the metal and to enhance the growth and yields of maize and barley (Hordeum vulgare). The $\mathrm{Zn}$ concentration in plant tissues was also reduced by the amendment. Knox et al. [60] reported that applying $2.5-5 \%$ zeolites to a metal-laden soil near a $\mathrm{Zn}-\mathrm{Pb}$ smelter substantially enhanced the growth of maize and oat (Avena sativa) and decreased the $\mathrm{Cd}, \mathrm{Pb}$, and $\mathrm{Zn}$ accumulations in the plant tissues. In contrast, neither plant could grow in the unamended soil. Mahmoodabadi [61] indicated that application of natural zeolites increased the shoot dry weight, the number and dry weight of the root nodule and abated the $\mathrm{Pb}$ toxicity to the soybean (Glycine max). However, there are also quite a few reports which indicated that application of zeolites reduced the growth of some crops and vegetables [62-64]. It is generally believed that use of Na-type zeolites resulted in release of $\mathrm{Na}^{+}$to the soil solution and negatively affected the plant growth even though the adverse effects of the heavy metals were alleviated. Therefore, using Ca-type zeolites for heavy metal remediation is preferred at the sites where revegetation is planned.

Additionally, possessing unique selectivity for $\mathrm{Cs}^{+}$and $\mathrm{Sr}^{2+}$, zeolites are also good remediation agents for trapping radioactive ${ }^{139} \mathrm{Cs}$ and ${ }^{90} \mathrm{Sr}$ from contaminated soils due to nuclear fallout, contact with water from reactor cooling reservoirs, or radioactive waste spills [13]. Similar to heavy metal remediation, the primary purpose of using natural zeolites is to immobilize radionuclides in the soil and to reduce or prevent the uptake of those by plants [13].

2.3.2. Iron Oxides Nanoparticles ( $\mathrm{nFeOs}$ ). As an important constituent of soil and an essential nutrient to plants and animals, iron $(\mathrm{Fe})$ is ranked the 4 th most abundant element in the earth. The Fe oxides found in soils and sediments usually occur as nanocrystals (5-100 nm in diameter) with reactive surfaces capable of sorbing a wide range of both inorganic and organic species through mechanisms such as surface complexation/surface precipitation [65]. Due to their prominent absorption capacity for toxins and their environmentally friendly characteristics, a variety of engineered iron oxide nanoparticles have been fabricated and applied to in situ water/soil remediation processes. For example, nanoFe oxides (nFeOs) solution can be pumped/spread directly to contaminated sites at low cost with negligible risks of secondary contamination. The intensively studied $\mathrm{nFeOs}$ for heavy metals removal from water/wastewater include goethite $(\alpha$-FeOOH, needle-like, $200 \mathrm{~nm} \times 50 \mathrm{~nm})$, hematite $\left(\alpha-\mathrm{Fe}_{2} \mathrm{O}_{3}\right.$, granular, $\left.75 \mathrm{~nm}\right)$, amorphous hydrous $\mathrm{Fe}$ oxides (particles, $3.8 \mathrm{~nm})$, maghemite $\left(\gamma-\mathrm{Fe}_{2} \mathrm{O}_{3}\right.$, particle, $10 \mathrm{~nm}$ ), and magnetite $\left(\mathrm{Fe}_{3} \mathrm{O}_{4}\right.$, particles, around $\left.10 \mathrm{~nm}\right)$ [66]. Those $\mathrm{nFeOs}$ have been widely researched for heavy metal removal form aqueous phase through adsorption. The target contaminants included $\mathrm{Cu}^{2+}, \mathrm{Cr}^{6+}, \mathrm{Ni}^{2+}, \mathrm{Pb}^{2+}, \mathrm{Cr}^{3+}, \mathrm{Zn}^{2+}, \mathrm{As}^{+5}$, and $\mathrm{As}^{+3}$ [66]. However, the use of $\mathrm{nFeOs}$ for contaminated soil reclamation has not been widely studied. But the capacity of the nanoparticles for removal of heavy metals from aqueous phase suggests that these particles are able to sequester the labile fractions of heavy metals from the soil solution through adsorption and thus reduce the availability and mobility of those toxins in the soils. Moreover, addition of industrial wastes rich in iron oxides to contaminated soils has been a common practice for heavy metal immobilization [6769], suggesting that mixing $\mathrm{nFeOs}$ with the mine soils could effectively immobilize the soil-bound toxic metals. Shipley et al. [70] applied As-spiked solution to a column packed with soil mixed with $15 \%\left(\mathrm{~g} \mathrm{~g}^{-1}\right)$ nanomagnetite and observed that negligible As concentrations occurred in the effluent for up to 132 days as the influent containing $100 \mu \mathrm{g} \mathrm{L}^{-1}$. As injected through the column at a rate of $0.3 \mathrm{~mL} \mathrm{~h}^{-1}$. Only $20 \%$ of the contaminant leached out after 208 days. A subsequent batch test suggested that the soil alone had no adsorption of As. Shipley and colleagues [70] also reported that As and other 12 heavy metals (V, Cr. Co, Mn, Se, Mo, $\mathrm{Cd}, \mathrm{Pb}, \mathrm{Sb}, \mathrm{Tl}, \mathrm{Th}$, and $\mathrm{U}$ ) could be simultaneously removed by the $\mathrm{nFeOs}$ in the soil. After 35 hours of the leaching test, only $\mathrm{Cr}, \mathrm{Mo}, \mathrm{Sb}$, and Co leaching reached more than $20 \%$ of the influent levels, revealing the fairly strong and high adsorption capacity of the nanoparticles even for multiple contaminants. Nanohematite has an adsorption capacity similar to the nanomagnetite [70].

Besides the chemical compositions, remediation efficiency and deliverability of the nanoparticles are largely controlled by their stability and transport behaviors in the media (water, soil, or aquifer). Stability and transport of $\mathrm{nFeOs}$ depend on the particle size, particle concentration, particle magnetism, the solution chemistry, and the medium property. For a given nanoparticle suspension, the particle stability is generally governed by the electrostatic repulsion between particles [71]. The force is generated by the particle surface charge. and surface "zeta potential" is used to quantify the magnitude of the charge or the electrostatic repulsion. The higher the zeta potential is, the stronger the repulsion force would be between particles, thus the more stable the nanosolution is. Charged ions (e.g., $\mathrm{H}^{+}, \mathrm{OH}^{-}$, $\mathrm{Na}^{+}$, or $\mathrm{Cl}^{-}$) in the background solution can affect the suspension stability by changing the particles surface charge 
(zeta potential). A pH value where the net surface charge becomes zero is called "point of zero charge" (PZC), and the solution is least stable and most prone to form aggregates at $\mathrm{pHs}$ close to the PZC. Therefore, the influences of a solution $\mathrm{pH}$ on the nanoparticles stability depend on how close the solution $\mathrm{pH}$ is to the particle PZC. For example, the PZC is at $\mathrm{pH} 7.1$ for magnetite nanoparticles. The suspension was not stable at pHs from 6 to 8 because the net particle surface change reduced to around zero and fast aggregation took place due to the minimum repulsion. In contrast, the nanoparticles solutions remained stable at $\mathrm{pHs}$ from 3 to 5 or from 9 to 10 , which were far from the PZC of magnetite nanoparticles [72]. In these cases, the average particle size remained similar to the original size $(60 \mathrm{~nm})$ [72].

Nanoparticles in a concentrated solution more likely collide with each other and form aggregates and precipitates than in a dilute solution, so the former solution is less stable than the latter $[73,74]$. He et al. [73] reported that aggregation rates were higher for smaller hematite nanoparticles due to changes of the surface properties with particles size changes. More importantly, for $\mathrm{nFeOs}$ with strong magnetism, the additional attractive force of magnetism among the particles increases the probability of aggregation. In other words, the stability and transport of magnetic nanoparticles are negatively influenced by a combination of electrostatic and magnetic interactions as observed by Hong et al. [75]. Through column test with sand media, they [75] reported that the less-magnetic nanoparticles eluted from the columns more than the more-magnetic particles. And the nonmagnetic $\mathrm{nFeOs}$ were transported the most. The majority of particles were retained at the column inlet for all transport experiments, with the greatest amount of retention being that of the magnetic nanoparticles, indicating that magnetically induced aggregation and subsequent straining resulted in greater retention in the column. Magnetic particles include maghemite $\left(\gamma-\mathrm{Fe}_{2} \mathrm{O}_{3}\right)$, magnetite $\left(\mathrm{Fe}_{3} \mathrm{O}_{4}\right)$, and zero valent iron $\left(\mathrm{Fe}^{0}\right)$, while hematite $\left(\alpha-\mathrm{Fe}_{2} \mathrm{O}_{3}\right)$ nanoparticles are nonmagnetic. On the other hand, transport of those magnetic nanoparticles might be controlled by the imposing of an external magnetic field to the system.

Natural organic matter is able to modify the nanoparticles surface and change the particle PZC when absorbed by the latter. Therefore, changes of a nanoparticle suspension stability by humic acids (HA) could be explained with how the acids affect the particle PZC. Adsorption of HA often results in a decrease of magnetite PZC towards the more acidic $\mathrm{pH}$ values, and the more $\mathrm{HA}$ is added to the solution, the lower PZC becomes. For example, Hu et al. [72] reported PZC of magnetite nanoparticles dropped from 7.1 (without $\mathrm{HA}$ ) to 5.8 at $2 \mathrm{mg} \mathrm{L}^{-1} \mathrm{HA}$ and to 3.77 at $3 \mathrm{mg} \mathrm{L}^{-1} \mathrm{HA}$. When the HA concentration was high enough (e.g., $10 \mathrm{mg} \mathrm{L}^{-1}$ ), the $\mathrm{PZC}$ was dropped to $\mathrm{pH}$ values out of the range ( $\mathrm{pH} 3-10)$ that is commonly encountered by the natural environment. In this case, the suspension shows the highest stability under normal conditions [72]. Similar results are also reported by others $[73,76]$. In addition, an increase of the solution ionic strength generally enhances the aggregation of the nanoparticles [72].
Iron oxides nanoparticles are generally believed to have low or no toxicity to the living organisms according to limited related reports. For example, Karlsson et al. [77] evaluated the ability of the metal oxides particles with varying sizes to cause cell death, mitochondrial damage, DNA damage, and oxidative DNA lesions after exposure of the human cell line A549. They concluded that the iron oxide $\left(\mathrm{Fe}_{2} \mathrm{O}_{3}\right)$ nanoparticles showed low toxicity and no clear difference between the different particle sizes. Auffan et al. [78] believed the organic coating on maghemite nanoparticles served as a barrier for a direct contact between particles and the cells (human fibroblasts), further reducing the possible toxic effects. They found that the coated $n F e O s$ produced weak cytotoxic and no genotoxic effects. One main mechanism behind the toxicity of manufactured metal nanoparticles is their ability to cause oxidative stress in cells by producing reactive oxygen species (ROS). ROS can damage proteins, lipids and DNA as well as give rise to necrosis and apoptosis [77]. However, Limbach et al. [79] believed that the chemical composition rather than the nanoscale size is a most decisive factor determining the formation of ROS in exposed cells. Moreover, they observed that dissolved iron ions promote a 20 times higher ROS production than exposure to the same amount of iron in the form of $\mathrm{Fe}_{2} \mathrm{O}_{3}$ nanoparticles, suggesting nanosized iron particles do not exert more toxicity than the soluble irons or solid irons with larger particle sizes. As a matter of fact, Sadeghiani et al. [80] suggested that polyaspartic-acid-coated magnetite nanoparticles may be considered as a potential precursor of anticancer drugs.

2.3.3. Nanoscale Zero-Valent Iron Particles (nZVI). Nanoscale zero-valent iron (nZVI) technology developed in 1990s was initially designed to destroy the toxic halogenated hydrocarbon compounds and other petroleum-related products which entered the ground water environment through gas tank leakage, organic solvent spills, etc. [81]. The metallic iron particles are highly effective reducing agents and able to convert several persistent organic contaminants to benign compounds by reduction reactions. These contaminants include chlorinated methanes, chlorinated benzenes, pesticides, polychlorinated biphenyls (PCBs), and nitroaromatic compounds [81]. In addition to the high decontamination effectiveness, this technology possesses the advantages of using an environmentally friendly material and being easily delivered to the subsurface environment due to the small particle size.

This technology is also used to treat heavy metals in water and soil. Zero valent iron is a strong reductant with a reduction potential $\left(E^{0}, \mathrm{Fe}^{2+} / \mathrm{Fe}^{0}\right)$ of $-0.44 \mathrm{~V}$ [71]. Theoretically, some metals with $E^{0}$ much more positive than $-0.44 \mathrm{~V}$ could be reductively immobilized by nZVI. Typical examples of such metals with environmental importance include $\mathrm{CrO}_{4}{ }^{2-} / \mathrm{Cr}^{3+}\left(E^{0}=+1.56 \mathrm{~V}\right), \mathrm{Cr}_{2} \mathrm{O}_{7}{ }^{2-} / \mathrm{Cr}^{3+}\left(E^{0}=+1.36 \mathrm{~V}\right)$, and $\mathrm{UO}_{2}{ }^{2+} / \mathrm{U}^{4+}\left(E^{0}=+0.27 \mathrm{~V}\right)[71]$. The high-valent species $\left(\mathrm{CrO}_{4}{ }^{2-}, \mathrm{Cr}_{2} \mathrm{O}_{7}{ }^{2-}\right.$, and $\left.\mathrm{UO}_{2}{ }^{2+}\right)$ of those metals are usually more soluble and more toxic than their low valent counterparts $\left(\mathrm{Cr}^{3+}\right.$ and $\left.\mathrm{U}^{4+}\right)$ in the natural environment. nZVI is able to transform the former to the latter through reduction reactions, thus decreasing the solubility/mobility and toxicity 
of those metals (the whole process is called reductive immobilization). For example, uranium (U) is the most common radionuclide contaminant found at many nuclear waste sites. It is mainly detected in contaminated groundwater as highly soluble and mobile $\mathrm{U}^{6+}$ in the form of $\mathrm{UO}_{2}{ }^{2+}[82]$. In soils and in uranium mining tailings, $\mathrm{UO}_{2}{ }^{2+}$ sorbs onto Fe oxyhydroxides [83]. However, acid mine drainage can dissolve and release the sorbed uranium to the nearby ecosystem. These risks can be remediated by reducing it to insoluble $\mathrm{U}^{4+}$ oxides by nZVI. Several related reports have shown that, compared to the other reductants such as metal iron filing, galena $(\mathrm{PbS})$, and iron sulfide, $\mathrm{nZVI}$ is very efficient to reductively immobilize $\mathrm{U}^{6+}$ from aqueous phase, which could be attributed to its nanosize, high reactivity, large surface area, and reactive Fe(II) produced by nZVI [84-88]. This literature confirmed that $\mathrm{U}^{6+}$ was predominantly removed by nZVI via reductive precipitation of $\mathrm{UO}_{2}{ }^{2+}\left(\mathrm{U}^{4+}\right)$ with minor precipitation of $\mathrm{UO}_{3} \cdot 2 \mathrm{H}_{2} \mathrm{O}\left(\mathrm{U}^{6+}\right)$ as confirmed by the $\mathrm{X}$ ray photoelectron spectroscopy (XPS) and X-ray diffraction (XRD) analyses. Oxygen level, solution $\mathrm{pH}$, and presences of bicarbonates and calcium ions all affect the reductive immobilization processes $[84,85]$. It has also been reported that nZVI was able to reduce higher valent $\mathrm{Cr}^{+6}$ to low valent $\mathrm{Cr}^{+3}$ in water or soil media. Franco et al. [89] reported that $97.5 \%$ of $\mathrm{Cr}^{+6}$ in a contaminated soil could be reduced to $\mathrm{Cr}^{+3}$ by nZVI, which significantly reduced the chromium toxicity in the spoil. Similar reductive immobilization of $\mathrm{Cr}^{+6}$ in soils by nZVI was reported by others [90, 91].

Selenium (Se) is an essential nutrient in animal systems, but high concentrations can threaten biological systems when human activities, such as mining into shale for oil and phosphorus or irrigating arid and semiaridlands, produce seleniferous soils [92]. Plants can accumulate Se from the impacted soils [93]. Plant accumulation and soil ingestion lead to Se bioaccumulation and Se poison in livestock and wildlife $[94,95]$. Similar to uranium and chromium, highvalent selenium species $\left(\mathrm{SeO}_{4}{ }^{-2}\right.$ or $\mathrm{Se}^{6+}$ and $\mathrm{SeO}_{3}{ }^{-2}$ or $\mathrm{Se}^{4+}$ ) are more soluble and mobile in the natural environment and more toxic than the low-valent species such as $\mathrm{Se}^{0}$ and $\mathrm{Se}^{-2}$. nZVI has been applied to remove the selenium from the solution and reduce the high-valent species to the lowvalent ones thus the toxicity and solubility of Se are greatly lowered [71]. Olegario et al. [96] reported that nZVI had high uptake capacity for removal of dissolved $\mathrm{Se}^{6+}$ up to 0.1 mole Se/mole Fe. Using X-ray absorption near edge structure (XANES) spectroscopy and X-ray absorption fine structure (EXAFS) spectroscopy, they identified FeSe compound in the solid phase as the reduced $\mathrm{Se}^{2-}$ species transformed from $\mathrm{S}^{6+}$. They concluded that nZVI was capable of an efficient reduction of soluble Se oxyanions to insoluble $\mathrm{Se}^{-2}$.

$\mathrm{nZVI}$ is also able to treat some other toxic elements in water or soil such as $\mathrm{Hg}^{+2}, \mathrm{Ni}^{+2}, \mathrm{Ag}^{+1}, \mathrm{Cd}^{+2}, \mathrm{As}^{+3}$, and $\mathrm{As}^{+5}$ [97-101]. The decontamination mechanisms include reduction of metal ions to zero valent metals on the nZVI surfaces and/or adsorption of the ions on the nZVI particle shells which consist of a layer of iron oxidation products (iron oxides) [71]. For example, Watanabe et al. [102] reported that applying $0.01 \% \mathrm{nZVI}\left(\mathrm{g} \mathrm{g}^{-1}\right)$ to a Cd-spiked soil significantly reduced the $\mathrm{Cd}$ accumulations in rice
(Oryza sativa) seeds and leaves by less than 10\% and 20\% of those without nZVI amendment.

The environmental migration of bare nZVI has been estimated to be within a few centimeters under subsurface environment $[103,104]$ due to quick nanoparticles agglomeration and interactions with surfaces of the ambient porous media. Substantial efforts have been made to increase the stability and mobility of nZVI (e.g., using nanoparticle stabilizers), hoping that nZVI disperses the entire contaminated aquifer and degrades the pollutants in situ as soon as being injected underground through one or more injection wells. Supported by the laboratory column test results, quite a few reports have claimed successful synthesis of nZVI with improved stability and mobility as well as reactivity [105108]. But there is no solid evidence on significantly increased mobility of such products in the field [71]. Stabilized nZVI has been visually confirmed to travel merely $1 \mathrm{~m}$ from an injection well, and evidence suggests that the maximum travel distance of up to $2-3 \mathrm{~m}$ may be achieved in high permeability formations [71]. The discrepancies between the lab reports and the field tests resulted from the fact that laboratory applied lower Fe concentrations $(<0.25 \mathrm{~g} / \mathrm{L})$, higher flow velocities (15-30 m/day), and simplified subsurface simulations by sand-packed columns. As a matter of fact, much higher Fe application rates $(1-30 \mathrm{~g} / \mathrm{L})$, lower groundwater flow rates $(0.1$ to $10 \mathrm{~m} /$ day $)$, and much more complicated aquifer formations were found under the field conditions [71], which favored aggregation and precipitation of nZVI. In addition, dissolved oxygen very rapidly oxidizes nZVI, forming maghemite and magnetite precipitates [109]. These facts suggest that risks of nZVI spills in the environment and subsequent exposure of organisms to the nZVI are not significant on the current stage of nZVI technology.

There is no field study on applying nanoparticles for soil remediation. However, there are some differences from groundwater remediation. For mine soil reclamation and vegetation establishment purposes, a thin soil surface layer (e.g., $50 \mathrm{~cm}$ deep) for plant root establishments is usually interested. Ideally, the nanoparticle suspension would be applied to all over the targeted land surfaces in a way similar to the surface irrigation. By manipulating the nanoparticle size, the particles would be ideally retained within the contaminated surface layer only after the whole targeted soil column was saturated and treated by the particles, thus reducing the risks of nanomaterials spill and avoiding secondary contaminations to the neighboring water bodies. From this point of view, nZVI and other nanoparticles with extremely high mobility are not needed for surface soil remediation purpose.

There is a limited number of peer-reviewed and published studies pertaining to the toxicological and ecotoxicological effects of nZVI application in the environment [110]. Based on available information, Grieger et al. [110] summarized the possible effects of exposure to nZVI as follows: (a) acute toxicity to aquatic organisms appears to be relatively low, and sublethal effects have been observed at lower concentrations $\left(<1 \mathrm{mg} \mathrm{L}^{-1}\right)$; (b) nZVI can attach to organisms and cells and cause histological changes and morphological alterations in some species; (c) some coatings 
have also been found to decrease toxicity mainly through reduced adherence; (d) effects are thought to be linked to the release of $\mathrm{Fe}(\mathrm{II})$ from nZVI and subsequent ROS production as well as disruption of cell membranes leading to cell death and lysis and possible enhancement of biocidal effects of $\mathrm{Fe}(\mathrm{II})$; (e) the aging of nZVI under aerobic conditions reduces nZVI toxicity, whereby $\mathrm{Fe}^{0}$ is rapidly oxidized

Other metal-based nanoparticles for environmental remediation encompass nanoscale manganese oxides and hydroxides, aluminum oxides, titanium oxides, zinc oxides, and magnesium oxides. All of those nanoparticles could remove heavy metal from solution by surface adsorption, a mechanism similar to that of heavy metal removal by iron oxides [65]. Among those metal oxides nanoparticles, iron and manganese nanoparticles are sensitive to the reduced environment such as those in a waterlogged soils or wetlands. Those particles may be reduced to the lower valent states and lose the adsorption capacity. For manganese, zinc, and aluminum-based nanoparticles, phytotoxicity might occur if those particles are applied to the acidic soils. Moreover, Limbach et al. [79] reported that cobalt and manganese oxides $\left(\mathrm{Co}_{3} \mathrm{O}_{4}\right.$ and $\left.\mathrm{Mn}_{3} \mathrm{O}_{4}\right)$ nanoparticles produced more ROS (indicating more toxicity) than their respective salt solutions while titanium oxide $\left(\mathrm{TiO}_{2}\right)$ and iron oxide $\left(\mathrm{Fe}_{2} \mathrm{O}_{3}\right)$ nanoparticles were relatively inert.

2.3.4. Phosphate-Based Nanoparticles. Different from $\mathrm{nFeOs}$ or nZVI, phosphate-based nanoparticles remediate the heavy metal-contaminated soils by forming highly insoluble and stable phosphate compounds. A typical example is treatment of the lead-laden soils. The solubility products of common lead compounds in soils such as anglesite $\left(\mathrm{PbSO}_{4}\right)$, cerussite $\left(\mathrm{PbCO}_{3}\right)$, galena $(\mathrm{PbS})$, and litharge $(\mathrm{PbO})$ have been measured as $10^{-7.7}, 10^{-12.8}, 10^{-27.5}$, and $10^{+12.9}$, respectively [111]. In comparison, lead phosphate compounds such as pyromorphites $\left(\left(\mathrm{Pb}_{5}\left(\mathrm{PO}_{4}\right)_{3} \mathrm{X}, \mathrm{X}=\mathrm{F}^{-}, \mathrm{Cl}^{-}, \mathrm{Br}^{-}\right.\right.$, and $\left.\mathrm{OH}^{-}\right)$ have solubility products less than $10^{-71}$ [111]. This fact indicates that lead phosphates are considerably less soluble than other $\mathrm{Pb}$ phases generally observed in soils. A transformation of the less stable $\mathrm{Pb}$ species to more stable species by phosphate amendments is a thermodynamically favored process which spontaneously decreases the leachability and availability of the lead in the solid phase. Some phosphate amendments have been the most effective method for in situ lead immobilization and have been intensively studied [111]. Other metals having been investigated and reported effective include $\mathrm{Cu}^{2+}, \mathrm{Zn}^{2+}, \mathrm{Cd}^{2+}, \mathrm{Co}^{2+}, \mathrm{Cr}^{3+}, \mathrm{Ba}^{2+}, \mathrm{U}^{6+}$, and $\mathrm{Eu}^{3+}[112-115]$. Generally, soluble phosphate salts and particulate phosphate minerals are commonly utilized forms of the phosphates for this purpose. The former includes phosphoric acid [116], $\mathrm{NaH}_{2} \mathrm{PO}_{4}$ [117], and $\left(\mathrm{NH}_{4}\right)_{2} \mathrm{HPO}_{4}$ [115], the latter involves various forms of apatite including synthetic apatites [118], natural rock phosphates [112, 115], and biogenic apatites such as fishbone [119]. Although both are highly effective for in situ stabilization of heavy metals at the laboratory scale, problems still exist in the application of these materials in the field. For instance, soluble phosphates, although highly mobile in the subsurface and thus more effective in heavy metal stabilization, may cause the secondary environmental problems of eutrophication. Furthermore, application of phosphoric acids and ammonium phosphates in large amounts may result in acidifying the soils [115]. Amendment dosage of $3 \% \mathrm{PO}_{4}$ (or $1 \%$ as $\mathrm{P}$ ) by weight for soils has been proposed and practiced by USEPA and other government agencies [120], suggesting higher possibility of the phosphate spill to water bodies and soil acidification following the heavy metal remediation.

Yet, the application of solid phosphate is hindered by the large size of the particles, which limits the phosphate mobility and delivery and prevents phosphate from reaching and reacting with heavy metals in subsoil layers. Even the finely ground solid phosphate particles are not mobile in soils, and mechanical mixing is usually needed but not practical in the field for in situ treatment processes. In light of these problems related to phosphates application, Liu and Zhao [52] synthesized nanosized iron phosphate particles for heavy metal immobilization as the commonly used phosphates while overcoming the delivery problem and secondary contamination risks associated with the latter. For example, the nanoparticle suspension, which possesses the same mobility as aqueous solution due to the nanoscaled particle size, is easily delivered to the contamination site with conventional engineering methods (e.g., spray or well-injection). The nanoparticles are also environmentally sound because the phosphate in solid form is much less bioavailable to the algae than those in soluble forms [121]. Algae-bioavailable $\mathrm{P}$ and $\mathrm{N}$ are primarily responsible for eutrophication in surface waters.

Liu and Zhao [52] prepared and tested a new class of iron phosphate (vivianite) nanoparticles for in situ immobilization of $\mathrm{Pb}^{2+}$ in soils. Batch test results showed that the nanoparticles could effectively reduce the leachability and bioaccessibility of $\mathrm{Pb}^{2+}$ in three representative soils (calcareous, neutral, and acidic), evaluated by the toxicity characteristic leaching procedure (TCLP) and physiologically based extraction test (PBET), respectively. When the soils were treated for $56 \mathrm{~d}$ at a dosage ranging from 0.61 to $3.0 \mathrm{mgg}^{-1}$-soil as $\mathrm{PO}_{4}{ }^{-3}$, the TCLP leachable $\mathrm{Pb}^{2+}$ was reduced by $85-95 \%$, and the bioaccessible fraction was lowered by $31-47 \%$. Results from a sequential extraction procedure showed a 33-93\% decrease in exchangeable $\mathrm{Pb}^{2+}$ and carbonate-bound fractions, and an increase in residual$\mathrm{Pb}^{2+}$ fraction when $\mathrm{Pb}^{2+}$-spiked soils were amended with the nanoparticles. Addition of chloride in the treatment further decreased the TCLP-leachable $\mathrm{Pb}^{2+}$ in soils, suggesting the formation of chloropyromorphite minerals. Compared to soluble phosphate used for in situ metal immobilization, application of the iron phosphate nanoparticles resulted in around 50\% reduction in phosphate leaching into the environment. Liu [53] also reported an effective remediation of a lead-laden soil from a shoot range using synthesized apatite nanoparticles. Laboratory tests exhibited that the apatite nanoparticles solution could effectively reduce the TCLP-leachable $\mathrm{Pb}$ fraction in the $\mathrm{Pb}$-contaminated soil from $66.43 \%$ to $9.56 \%$ after one-month amendment at a ratio of $2 \mathrm{~mL}$ solution to $1 \mathrm{~g}$ soil and the resulting $\mathrm{Pb}$ content in the TCLP solution was reduced to $12.15 \mathrm{mg} \mathrm{L}^{-1}$ from 
$94.33 \mathrm{mg} \mathrm{L}^{-1}$. When the amendment ratio was increased by 5 times, the leachable $\mathrm{Pb}$ was reduced to $3.75 \mathrm{mg} \mathrm{L}^{-1}$ with only about $3 \%$ of the soil $\mathrm{Pb}$ leachable. The original soil sample contained an average of $2647.9 \mathrm{mg} \mathrm{Pb} \mathrm{kg}^{-1}$ soil [53].

These phosphate-based nanoparticles also have potentials to be used as $\mathrm{P}$ nanofertilizers. In addition to providing nutrient $\mathrm{P}$ to the plants, these nanoparticles also have the advantage of easy delivery (by spraying to the soil surface) with least $\mathrm{P}$ leaching to the neighboring water bodies.

2.3.5. Iron Sulfide Nanoparticles. Similar to the mechanisms of heavy metal immobilization by the phosphatebased nanoparticles, sulfide-based nanoparticles have been researched specifically to eliminate the contaminations of mercury $(\mathrm{Hg})$ and arsenic (As) in water and soil/sediment by providing sulfide $\left(\mathrm{S}^{-2}\right)$ ligands and/or coordination surfaces. As a matter of fact, reduced sulfur $\left(\mathrm{S}^{2-}\right)$ has been regarded as a stabilizer/sink of heavy metals in the reduced environment such as in the sediments or water-logged soils by forming highly insoluble metal sulfides [122]. It has been proposed that a sediment sample would be regarded safe or nontoxic to the aquatic organisms if the molar ratio of the acid volatile sulfide (AVS) to the total heavy metal concentrations (e.g., $\mathrm{Cu}+\mathrm{Ni}+\mathrm{Zn}$ ) was greater than 1 [123]. In this case, theoretically, the heavy metals are all bound in the insoluble metal-sulfide phases and thus the soluble (bioavailable) metals in the pore water are minimized [123]. Moreover, sulfide $\left(\mathrm{S}^{2-}\right)$ has been widely believed as the most important inorganic ligand to remove the $\mathrm{Hg}$ from the water column and suppress the formation of the notorious methyl-mercury $\left(\mathrm{CH}_{3} \mathrm{Hg}\right)$ in the natural environment. Methyl-mercury has been believed as is one of the most toxic $\mathrm{Hg}$ species which can easily bioaccumulate in fish and other aquatic organisms and become biomagnified through food webs. Consumption of fish and shellfish contaminated with $\mathrm{CH}_{3} \mathrm{Hg}$ is the primary route of human exposure to mercury [124]. Dissolved, neutral mercury complexes (primarily $\mathrm{HS}^{0}$ and $\mathrm{Hg}(\mathrm{HS})_{2}{ }^{0}$ ) rather than $\mathrm{Hg}^{2+}$ or total dissolved $\mathrm{Hg}$ are considered the main $\mathrm{Hg}$ (II) species controlling the extent of mercury methylation in the contaminated sediments $[125,126]$. Iron sulfide amendments can effectively decrease the concentrations of the neutral mercury complexes by formation of charged $\mathrm{Hg}$ (II)-polysulfides (e.g., $\mathrm{HgS}_{2}{ }^{2-}, \mathrm{HgSH}^{+}, \mathrm{HgS}_{2} \mathrm{H}^{-}$) $[124,127]$. In addition, formation of the insoluble mercuric sulfide complexes also reduces conversion of the ionic $\mathrm{Hg}$ to volatile metal $\mathrm{Hg}$ in soil [128]. Liu et al. [124] reported that synthesized mackinawite (FeS) was able to remove the aqueous $\mathrm{Hg}$ around $0.75 \mathrm{~mol} \mathrm{Hg}{ }^{2+} /$ mole FeS. They believed that $77 \%$ of $\mathrm{Hg}$ removed was through precipitation by forming in soluble $\mathrm{HgS}$ species and the remaining 23\% was removed by adsorption on the FeS surface. Meanwhile, under anoxic environments, iron sulfides are also able to reduce the mobility and availability of toxic element As by adsorption and/or precipitation processes, depending on the solution $\mathrm{pH}$ and iron sulfide type and oxidation state of As [129-132]. For example, Wolthers et al. [130] reported that the maximum $\mathrm{As}(\mathrm{V})$ adsorption by FeS occurred at pH 7.4 with an adsorption capacity of $0.044 \mathrm{~mol} \mathrm{As} / \mathrm{mol} \mathrm{FeS}$ while the capacity was $0.012 \mathrm{As} / \mathrm{mol} \mathrm{FeS}$ to As(III) but less
$\mathrm{pH}$ dependent. Furthermore, the reduction capacity of iron sulfides is also applied to reductive immobilization of $\mathrm{Tc}^{+6}$ [133], $\mathrm{Cr}^{+6}$ [134], and $\mathrm{U}^{+6}$ [135], and reductive degradation of trichloroethylene (TCE) and tetrachloroethylene (PCE) [136-138]. Again, sulfide ion $\left(\mathrm{S}^{2-}\right)$ plays major role in those reduction reactions, and the decontamination mechanisms are similar to those of zero-valent iron nanoparticles as discussed in Section 2.3.3.

Mackinawite is a widely reported iron sulfide synthesized for those environmental remediation studies in the laboratory. This compound is prepared by simply mixing $\mathrm{Fe}^{2+}$-containing and $\mathrm{S}^{2-}$-containing salts together under anaerobic condition. This method produces black-colored micrometer-sized particles [121, 127, 133], which aggregate and precipitate in a few minutes [127]. Using carboxymethylcellulose (CMC) as nanoparticle stabilizer, Xiong et al. [127] synthesized stable FeS spherical nanoparticle suspension which reportedly remained suspended for at least 3 months with the final average particle size of $31.4 \pm 4 \mathrm{~nm}$. Dentrimer was also used as a stabilizer to prepare FeS nanoparticles by Shi et al. [139], forming spherical-shaped particles with 4$6 \mathrm{~nm}$ diameter. Xiong et al. [127] showed that the CMCstabilized nanoparticles were highly effective to immobilize $\mathrm{Hg}$ in a sediment sample. For instance, when the FeS-to$\mathrm{Hg}$ (sediment-bound) molar ratio was increased to 26.5 , the $\mathrm{Hg}$ concentration in the sediment pore water was reduced by $97 \%$ and the TCLP leachability of the sediment-bound $\mathrm{Hg}$ was reduced by $99 \%$, suggesting the FeS nanoparticles amendment greatly reduced the labile $\mathrm{Hg}$ portion in the sample. Hg speciation modeling in their study also indicated that the FeS amendment greatly reduced the concentration of the bioavailable $\mathrm{Hg}$ species $\left(\mathrm{HgS}^{0}+\mathrm{Hg}(\mathrm{HS})_{2}{ }^{0}\right)$ by up to three orders of magnitude. Most importantly, the stabilized FeS suspension was highly mobile in a clay loam sediment column, reflecting the intrinsic properties of the nanoparticles and the high deliverability for soil/sediment remediation. They reported that complete breakthrough of the nanoparticles occurred at around 18 pore volumes (PVs), compared to $3 \mathrm{PVs}$ for the inert tracer $\left(\mathrm{Br}^{-}\right)$. In contrast, when nonstabilized FeS particles were subjected to the same tests, nearly all $(>99.7 \%)$ the particles were intercepted on top of the sediment column [127]. Xiong et al.'s work is probably the only one using real FeS nanoparticles to remediate the soil-bound contaminants $(\mathrm{Hg})$. But literatures cited earlier in this section suggest that FeS nanoparticles would be excellent candidates for in situ immobilization of other heavy metals (especially As) and some organic pollutants bound in soils or in sediments.

However, cautions must be taken when a mine soil reclamation plan is proposed to use FeS: first of all, most of the iron sulfide $\left(\mathrm{S}^{-}\right)$solids are not stable under the aerobic environments and are easily oxidized to soluble sulfate species $\left(\mathrm{SO}_{4}{ }^{2-}\right)$ by the air $[122,133]$, thereby their adsorption capacity is lost and the contaminants already retained on the FeS solid surface would be rereleased to the pore water and become remobilized [122]. Processes such as draining a pond or a water-logged land and dredging the sediments are a few examples of exposing the sediments to 
the air. Practically, it is difficult to maintain a soil/sediment under anaerobic environment for long period, and a change of the redox potential might cause a secondary contamination problem related to FeS amendments. Secondly, acid mine drainage (AMD) is one of the serious environmental concerns at most of the abandoned mining sites. Huge efforts have been made on research, prevention, management, and remediation of AMD and acidic mine soils for many decades [140]. As a matter of fact, the acidity in the drainage and in the soils originates from oxidation of the iron sulfide minerals (mostly pyrite, $\mathrm{FeS}_{2}$ ) by oxygen $\left(\mathrm{O}_{2}\right)$ after these buried minerals were exposed to the air through the mining operations [140]. Therefore, simply adding the FeS minerals to the soils as suggested by the literatures cited above might exacerbate the AMD and soil acidity problems at a mining site. More stable immobilization agents such as iron oxide nanoparticles (for As) or phosphate-based nanoparticles (for heavy metals) should be better options.

2.3.6. Carbon Nanotubes. The C nanotubes (CNTs) are C macromolecules consisting of sheets of $\mathrm{C}$ atoms covalently bonded in hexagonal lattices that seamlessly toll into a hollow, cylindrical shape with both ends normally caped by fullerene-like tips [141]. Based on the structures, CNTs are categorized into two main classes: single-walled $\mathrm{C}$ nanotubes (SWCNT) and multiwalled C nanotubes (MWCNT). The lengths of CNTs can range from several hundred nanometers to several micrometers, and the diameters from 0.2 to $2 \mathrm{~nm}$ for SWCNT and from 2 to $100 \mathrm{~nm}$ for coaxial MWCNT. The large surface area, tubular structure, and nonpolar property make CNTs a promising adsorbent material for nonpolar organic contaminants in an environmental media, such as trihalomethanes, polycyclic aromatic hydrocarbons, or naphthalene, dioxin, herbicides, DDT and its metabolites $[22,23,141]$. Compared to an activated C, the purified CNTs possess two to three times higher adsorption capacities for organic contaminants [22].

Due to the nonpolar property of the $\mathrm{C}$ material, sorption of the polar metal ions by raw CNTs is very low but significantly increases after the CNTs surface is chemically modified and a large amount of oxygen-containing polar functional groups $(-\mathrm{COOH},-\mathrm{OH}$, or $-\mathrm{C}=\mathrm{O})$ are created. These functional groups cause a rise in negative charge on $\mathrm{C}$ surface, and the oxygen atoms in functional groups donate single pair of electrons to metal ions, consequently increasing the cation adsorption capacity of CNTs [142]. For example, MWCNTs, pretreated with nitric acid, have been used successfully for the sorption of different heavy metal ions, including $\mathrm{Pb}$ (II) (97.08 $\mathrm{mg} \mathrm{g}^{-1}$ ), $\mathrm{Cu}$ (II) $\left(24.49 \mathrm{mg} \mathrm{g}^{-1}\right)$, and $\mathrm{Cd}$ (II) (10.86 $\left.\mathrm{mg} \mathrm{g}^{-1}\right)$ from an aqueous solution. In addition, SWCNTs and MWCNTs have better Ni(II) sorption properties following their oxidation with $\mathrm{NaClO}$. These treatments improve polarity of the CNT surface, resulting in them becoming more hydrophilic and, therefore, able to sorb more charged metal ions from the aqueous solution $[143,144]$.

While the above-mentioned studies indicate that CNTs are potentially efficient adsorbents for a variety of pollutants in both drinking and environmental waters, their practical application may be hampered by their high cost [22]. However, CNTs could be applied at small amounts (thus at low cost) to the municipal sludge or to other solid wastes to absorb various organic contaminants so that these wastes could be safely land-applied to increase soil quality and minimize the waste-disposal expenses (see Sections 2.4 and 3).

The pristine CNTs are prone to aggregation and precipitation in the aqueous phase due to their extreme hydrophobicity $[145,146]$. Dispersion of CNTs in the aqueous phase can be achieved either by modifying the surface structure and introducing hydrophilic (polar) functional groups $[146,147]$ or by improving the interactions on the nanotubes/water interface through addition of surfactants [148], polymers [149], and natural organic matter [145, 147, 150]. The former method directly enhances the hydrophility of the CNTS, while the latter options not only create a thermodynamically suitable surface in water but also provide steric or electrostatic repulsion among dispersed CNTs, thus preventing aggregation [145]. Natural organic matter may play important roles in fate and transport of nanotubes in the environment because of its ubiquitous presence. Hyung et al. [145] reported that the water samples taken from the Suwannee River, USA, showed a similar MWCNT stabilizing capacity as compared to fabricated solutions containing the model natural organic matter (SR-NOM). For the same initial MWCNT concentrations, the concentrations of suspended MWCNTs in SR-NOM solutions and the Suwannee River water samples were even considerably higher than that in a solution of $1 \%$ sodium dodecyl sulfate, a commonly used surfactant to stabilize CNTs in the aqueous phase.

Through studying the transport of carboxyl-functionalized SWCNTs in quartz-sand packed columns, Jaisi and Elimelech [146] and Jaisi et al. [147] concluded that the behaviors of the nanotubes were generally comparable to those traditionally observed with colloidal particles and bacterial cells. For example, an increase of the solution ionic strength resulted in increased SWCNT deposition in the column and divalent cations (e.g., $\mathrm{Ca}^{2+}$ ) reduce the SWCNT stability much more effectively than monovalent cations (e.g., $\mathrm{Na}^{+}$) at the same ionic strength. However, at very low ionic strengths even in DI water, SWCNT disposition in the sand media changed slightly, implying that the simply physical constrains (straining) also played roles in nanotube transport besides the complicated physicochemical interactions between particle and the medium surfaces. As concluded by Jaisi and Elimelech [146], straining may play more important roles on nanotube transport in the soil media. They compared the transport of linear nanotubes and spherical fullerene nanoparticles in columns packed with the same soils. It was found that the fullerene deposition rates were much lower than those of SWCNTs at the same ionic strength. Furthermore, fullerene nanoparticles were more sensitive to changes in ionic strength compared to SWCNTs. The authors proposed that linear shape and structure, particularly the very large aspect ratio and its highly bundled (aggregated) state in aqueous solutions, were mainly responsible for nanotube retentions in the soil columns. Moreover, the pore size distribution and pore geometry as well as heterogeneity in soil particle size, porosity, and permeability 
also contribute to straining in flow through the soil media by nanotubes. Thus, SWCNT transport in soils would be limited [147]. Similarly limited mobility was also reported on MWCNTs [151]. On the other hand, natural soil environments are more heterogeneous and normally contain open soil structures (e.g., cracks, fissures, worm trails, and other open features) that can promote preferential flow of SWNTs in soil. Additionally, soil pore water is normally rich in dissolved organic molecules (e.g., humic and fulvic acids) that can enhance the colloidal stability of nanomaterials [147].

Since there is limited number of publications of systemically studying the nanoparticles transport in the soil media, the discussions above showed significant implications on mobility of all types of nanoparticles in the soil environment. On one hand, nanoparticles may show decreased transport and higher retention rate in soil media than what were observed using sand-packed column tests in the laboratory due to the more complicated pore structures and pore distributions in soils. On the other hand, presence of the preferential flow and natural organic matter in soil media would enhance the nanoparticles mobility through the soil columns and increase the risks of groundwater contamination.

Studies have shown that CNTs are biologically active as demonstrated by a pulmonary response via induction of pulmonary granulomas $[152,153]$ at a greater instance than quartz (1-3 $\mu \mathrm{m}$ crystalline silica), which is a recognized chronic occupational health hazard (via inhalation routes). Both SWCNTs and MWCNTs were also attributed to cause loss of phagocytic ability and ultrastructure damage to alveola macrophages [154]. Furthermore, CNTs have induced observable toxic responses in other cell cultures $[155,156]$.

2.4. Using Nanoenhanced Materials as Solid Waste Stabilizers/Conditioners. Most solid wastes often contain environmental detrimental impurities, pathogens, and sometimes nauseous odors. Thus, beneficial reuses of such materials as resources in soil reclamation are limited by the concerns over secondary environmental contaminations. Through amendments, nanoenhanced materials might be able to increase the environmental safety and public acceptance of the waste application in reclaiming the mine soils or agricultural lands. For example, Li et al. [157] indicated that a small amount of nZVI ( $0.1 \%$ by weight) effectively removed the organic sulfur compounds (responsible for nuisance odors), heavy metals, and organic contaminants in the bio-solids, suggesting nZVI could reduce the detrimental effect of biosolids and enhance beneficial uses of these organic and nutritious solids. Turan [158] observed that cocompost of poultry litter with natural zeolites at a ratio of $5 \%$ and $10 \%\left(\mathrm{~g} \mathrm{~g}^{-1}\right)$ resulted in $66 \%$ and $89 \%$ reduction of the end product salinity, respectively. Zeolites can absorb the toxic metals $(100 \%$ of Cd, $28-$ $45 \%$ of $\mathrm{Cu}, 10-15 \%$ of $\mathrm{Cr}, 50-55 \%$ of $\mathrm{Ni}$ and $\mathrm{Pb}$, and $40-$ $46 \%$ of $\mathrm{Zn})$ in the biosolids at rates of $25 \%-30 \%\left(\mathrm{~g} \mathrm{~g}^{-1}\right)$ and reduce the leaching of these metals [159]. Nissen et al. [160] reported that addition of $0.5 \%$ and $1.0 \%$ zeolite over a 90-day period significantly reduced labile $\mathrm{Zn}$ in an experimental horticultural compost derived from sewage sludge. Subsequent plant growth trials measuring transfer of
$\mathrm{Zn}$ and $\mathrm{Cu}$ to ryegrass in successive harvests demonstrated that $1.0 \%$ zeolite caused significant reduction in total metal transfer from soil to plant over a $116 \mathrm{~d}$ growth period. The use of zeolites is a cost-effective amendment for compost to significantly reduce potential for soil metal mobility and soil to plant transfer [160]. Villaseñor et al. [161] added three commercial natural zeolites to a pilot-scale rotary drum composting reactor, where the domestic sewage sludge and barley straws were cocomposted. They observed that all three types of zeolites removed $100 \%$ of $\mathrm{Ni}, \mathrm{Cr}, \mathrm{Pb}$, and significant amounts (more than 60\%) of $\mathrm{Cu}, \mathrm{Zn}$, and $\mathrm{Hg}$ originated from the sludge [161]. It is also reported that the clinoptilolites reduced $50 \%$ of the $\mathrm{NH}_{3}$ emission from the compost [161], avoiding $\mathrm{N}$ loss and unpleasant odor from the compost. Villaseñor et al. [161] claimed that addition of $10 \%$ zeolites produced composts compliant with Spanish regulations regarding heavy metal contamination. According to them, the zeolite-amended compost could either be applied directly to soil, or the metal-polluted zeolites could be separated from the compost prior to application to ensure the environmental safety. Using zeolites as heavy metal absorbents in compost is also verified by other researchers [162-164]. Gadepalle et al. [165] applied compost containing 5\% zeolite to an As-contaminated soil and observed that zeolites addition can effectively reduce the As uptake by rye grass and that less than $0.01 \%$ of the total As content in the soil may be absorbed by the plants.

Literature above showed that amending the solid wastes with relatively small amounts of nanomaterials could effectively reduce or eliminate the risk of secondary contamination associated with land applications of these wastes. This practice could expand the industrial or municipal waste lists which are safe for land application, thus saving the cost of waste disposal and ameliorating the adverse environmental impacts. In addition, agricultural soils and drastically disturbed lands (e.g., mine soils) could benefit from these most cost-effective waste materials (soil amendments). Moreover, application of the nanomaterials to stabilize or condition the conventional soil amendment materials (e.g., composts, biosolids, coal combustion by-products) could be a potential aspect of utilization of nanotechnology in the agriculture at low cost. Zeolites, nFeOs, phosphate-based nanoparticles, and sulfide-based nanoparticles are efficient in immobilizing inorganic contaminants in the solids, while $\mathrm{C}$ nanotubes have a high absorption capacity for organic pollutants and nZVI can destroy the OWCs present in the wastes by reduction reactions. Finally, incubation of the nanomaterials with solid wastes could in turn stabilize the former and reduce the risks of nanomaterials spill and contaminations resulting from direct application of the nanoparticles to the environment.

\subsection{Using Nanoenhanced Materials to Control Soil Erosion.} Soil erosion caused by rainfall or wind in a closed mining site, especially before vegetation is established, can result in loss of good soil, exposure of the buried sulfide minerals, and transportation of the sediments and contaminants to the nearby surface water bodies. Thus, soil erosion control is a high priority in a mine soil reclamation plan. 
Nanoenhanced materials have been used to combat the soil erosion problems. Andry et al. [166] applied 10\% of a Catype zeolite material to an acidic soil and tested surface runoff and soil loss under simulated rainfall. They observed that the surface runoff and soil loss can be substantially reduced by zeolite application because of an increase in wet aggregate stability and the large particle size of the sediment due to the amendments. The authors [166] claimed that zeolites can be more effective than lime in control soil erosion. Yamamoto et al. [167] also observed the decrease of runoff rate and soil loss in sodic soils mixed with $\mathrm{Ca}$ type of artificial zeolite at rates of $5-25 \%$. They assumed that the exchange of $\mathrm{Ca}^{2+}$ on zeolites with $\mathrm{Na}^{+}$in the sodic soil reduced the clay dispersion, resulting in increased soil hydraulic conductivity and soil aggregation. Zheng [168] applied polyacrylamide (PAM, a polyelectrolyte used for soil erosion control) and magnetite nanoparticles to an As-spiked soil subject to the simulated rainfall and concluded that PAM could effectively reduce soil erosion while the nanoparticles could reduce As leaching. Wang et al. [169] examined the effects of alumina nanoparticles $\left(\mathrm{Al}_{2} \mathrm{O}_{3}, 140-330 \mathrm{~nm}\right)$ and a cationic polyelectrolyte in conditioning a wastewater treatment sludge and reported that this amendment can result in larger flocs and better dewatering effects than the single conditioning by polyelectrolyte only. The beneficial effects are more pronounced when finer nanoparticles $(140 \mathrm{~nm})$ were used. Wang and colleagues [169] proposed that the nanoparticles can enhance the stretch of the chain-like structures of the polyelectrolyte, resulting in more effective bridging effects and better flocculation. As a matter of fact, the PE (polyelectrolyte)—NP (nanoparticles) flocculation systems have been widely used in effectively removing solid particles from the solution [170, 171]. The flocculation in such a system is induced by the sequential addition of a positively charged polyelectrolyte followed by negatively charged nanoparticles, such as bentonite and colloidal silica. The systems produce a better flocculation and drainage (dewatering) than conventional polymer-only flocculation systems [170]. These results suggest that dual application of polyelectrolyte and nanoparticles could enhance flocculation and increase soil particle size and particle stability and thus effectively control soil erosions caused by wind or rain.

\section{Summary: Toward a Practical Strategy in Applying Nano-Technology in Mine Soil Reclamation and Agriculture}

Mine soil reclamation and rehabilitation can benefit from local environmental protection, provide additional land for forest or agricultural uses, and offset the atmospheric $\mathrm{CO}_{2}$ increase through $\mathrm{C}$ sequestration. Yet, the drastically disturbed land surfaces usually have poor soil quality where the desired plant species such as trees and crops are difficult to establish. Although some industrial, agricultural, and municipal wastes could be applied to the mining sites as soil amendments to improve soil quality, environmentally sensitive impurities contained in these wastes hinder the wide application of such materials. A synthesis of literature presented in this paper supports the hypothesis that the nanoenhanced materials, which have been successfully used in industry and other areas as new emerging materials with unique properties, could also be used as amendments to improve the quality of mine and agricultural soils at high efficiency. Although the data in support of this hypothesis are limited, the literature indicates that zeolites, nanoiron oxide particles, nanozero valent iron particles, nano-phosphatebased particles, nanosulfide-based particles, carbon nanotubes can improve soil physical and chemical properties, enhance soil fertility, stabilize soil contaminants, or reduce soil erosion. Mobility of nanoparticles in the soil columns is generally limited and spill of the nanomaterials should not be an issue although preferential flow and the dissolved organic matter might enhance mobility and transport of the particles. Iron-based nanoparticles, derived from environmental friendly Fe compounds, generally have low ecotoxicological effects. Thus, these nanoparticles are promising candidates for use in mine soil reclamation as well as for improving quality of agricultural soils.

One of the most important factors impeding a wide application of nanotechnology in agriculture is the cost of the nano-materials. However, natural nano-materials such as zeolites are usually not very costly. The average price for clinoptilolite granules is about $\$ 145$ per $\mathrm{Mg}$ (tonne), and some of the modified clinoptilolite and activated chabazite products are sold for as much as $\$ 8$ per $\mathrm{kg}$ [172]. For some other nanoparticles, which could be made in situ, the price depends on the chemicals used to synthesize the particles. The cost of nZVI is about $\$ 50-100 \mathrm{~kg}^{-1}$ [173], and nanoiron oxides, nanoiron phosphates, and nanoiron sulfides should be in the similar price range since the fabrication methods are similar. In comparison, CNTs are relatively expensive. The retail price of SWCNTs was $\$ 50$ per $g$ in the year of 2000 [174]. However, the prices of nanoparticles are always higher compared with the conventional soil amendment materials such as fly ash, manures, composts, or biosolids, which are often free to use.

Therefore, a practical strategy is proposed to make a feasible use of the nanotechnology in soil reclamation. The strategy is to (a) mix the suitable nanoparticles with the conventional amendment materials at small quantities, (b) stabilize the solid wastes to a certain degree and eliminate the risks of secondary contaminations by absorbing/immobilizing the heavy metals and organic toxins, and (c) apply the nanomaterial-amended wastes to mine soils or agricultural soils for better crop/vegetation establishments. Because of high effectiveness of the nanoparticles, $1-10 \%$ nanoparticles by weight are usually adequate to minimize the contamination problems associated with in the solid wastes. For instance, assuming a rate of $10 \mathrm{Mgha}^{-1}$ of biosolids is applied to a mining site for reclamation, according to [157], only $0.1 \%$ of zNVI is needed to stabilize the bio-solid [157]. In other words, only $10 \mathrm{~kg} \mathrm{ha}^{-1} \mathrm{nZVI}$ is required, which is a cost-effective rate of application of nanoparticles as soil amendment. Therefore, application of nanoparticle-stabilized conventional soil amendment materials is a practical approach to use nanotechnology for mine soil reclamation and for agriculture. Meanwhile, incubation 
of the highly reactive nanoparticles with solid wastes could reduce the risks of direct release of the nanoparticles to the environment and toxicity of nanoparticles to the plants.

However, there is few research or practical examples of using nanotechnology for soil reclamation. Therefore, assessing the effectiveness of nanoparticles in mine soil reclamation and vegetation establishments is a researchable priority. A high priority must also be given to studying the feasibility of using nanoparticle-stabilized solid wastes and of developing nanofertilizers.

\section{Acknowledgment}

This project was funded by the Office of Ohio Development.

\section{References}

[1] P. L. Younger, "Environmental impacts of coal mining and associated wastes: a geochemical perspective," Geological Society Special Publication, no. 236, pp. 169-209, 2004.

[2] F. G. Bell and L. J. Donnelly, Mining and Its Impact on the Environment, Taylor \& Francis, New York, NY, USA, 2006.

[3] S. F. Greb, C. F. Eble, D. C. Peters, and A. R. Papp, Coal and the Environment, American Geological Institute, Alexandria, Va, USA, 2006.

[4] W. L. Daniels, B. Stewart, and C. E. Zipper, Reclamation of Coal Refuse Disposal Areas VCE publication 460-131, www.http://ww.pubs.ext.vt.edu/460-131.html, 2010.

[5] D. A. N. Ussiri and R. Lal, "Carbon sequestration in reclaimed minesoils," Critical Reviews in Plant Sciences, vol. 24, no. 3, pp. 151-165, 2005.

[6] M. Sperow, "Carbon sequestration potential in reclaimed mine sites in seven east-central states," Journal of Environmental Quality, vol. 35, no. 4, pp. 1428-1438, 2006.

[7] M. Pietrzykowski and W. Krzaklewski, "Potential for carbon sequestration in reclaimed mine soil on reforested surface mining areas in Poland," Natural Science, vol. 2, pp. 10151021, 2010.

[8] R. K. Shrestha, R. Lal, and P. A. Jacinthe, "Enhancing carbon and nitrogen sequestration in reclaimed soils through organic amendments and chiseling," Soil Science Society of America Journal, vol. 73, no. 3, pp. 1004-1011, 2009.

[9] K. C. Haering, W. L. Daniels, and S. E. Feagley, "Reclaiming mined lands with biosolids, manures and papermill sludges," in Reclamation of Drastically Disturbed Lands, R. I. Barnhisel, R. G. Darmody, and W. L. Daniels, Eds., pp. 615-644, American Society of Agronomy, Soil Science Society of America, Soil Science Society of America, Madison, Wis, USA, 2000.

[10] F. J. Larney, O. O. Akinremi, R. L. Lemke, V. E. Klaassen, and H. H. Janzen, "Soil responses to topsoil replacement depth and organic amendments in wellsite reclamation," Canadian Journal of Soil Science, vol. 85, no. 2, pp. 307-317, 2005.

[11] L. S. Forsberg and S. Ledin, "Effects of sewage sludge on $\mathrm{pH}$ and plant availability of metals in oxidising sulphide mine tailings," Science of the Total Environment, vol. 358, no. 1-3, pp. 21-35, 2006.

[12] E. S. Bendfeldt, J. A. Burger, and W. Lee Daniels, "Quality of amended mine soils after sixteen years," Soil Science Society of America Journal, vol. 65, no. 6, pp. 1736-1744, 2001.

[13] D. W. Ming and E. R. Allen, "Use of natural zeolites in agronomy, horticulture and environmental soil remediation," in Natural Zeolites: Occurrence, Properties, Applications, D. W.
Ming and D. B. Bish, Eds., pp. 619-654, Mineralogical Society of America, Geochemical Society,Saint Louis, Mo, USA; Italian National Academy, Accademia Nationale dei Lincei (ANL), Barcelona, Italy, 2001.

[14] W. A. Dick, R. C. Stehouwer, J. M. Bigham et al., "Beneficial uses of flue gas desulfurization by-products: examples and case studies of land application," in Land Application of Agricultural, Industrial, and Municipal By-Products, J. F. Power and W. A. Dick, Eds., pp. 505-536, Soil Science Society of America, Madison, Wis, USA, 2000.

[15] D. K. Bhumbla, R. N. Singh, and R. F. Keefer, "Coal combustion by-product utilization for land reclamation," in Reclamation of Drastically Disturbed Lands, R. I. Barnhisel, R. G. Darmody, and W. L. Daniels, Eds., pp. 489-512, American Society of Agronomy, Soil Science Society of America, Soil Science Society of America, Madison, Wis, USA, 2000.

[16] W. L. Daniels, B. Stewart, K. C. Haering, and C. E. Zipper, "The potential for beneficial reuse of coal fly ash in southwest Virginia mining environments," Publication 460-134, Virginia Cooperative Extension (VCE), Stanardsville, Va, USA, 2002.

[17] P. A. Jacinthe and R. Lal, "Carbon storage and minesoil properties in relation to topsoil application techniques," Soil Science Society of America Journal, vol. 71, no. 6, pp. 17881795, 2007.

[18] R. B. Clark, K. D. Ritchey, and V. C. Baligar, "Benefits and constraints for use of FGD products on agricultural land," Fuel, vol. 80, no. 6, pp. 821-828, 2001.

[19] G. A. O’Connor, H. A. Elliott, N. T. Basta et al., "Sustainable land application: an overview," Journal of Environmental Quality, vol. 34, no. 1, pp. 7-17, 2005.

[20] C. A. Kinney, E. T. Furlong, S. D. Zaugg et al., "Survey of organic wastewater contaminants in biosolids destined for land application," Environmental Science and Technology, vol. 40, no. 23, pp. 7207-7215, 2006.

[21] J. Kim, "Preface," in Advances in Nanotechnology And the Environment, J. Kim, Ed., Pan Stanford Publishing, Singapore, Singapore, 2012.

[22] J. Theron, J. A. Walker, and T. E. Cloete, "Nanotechnology and water treatment: applications and emerging opportunities," Critical Reviews in Microbiology, vol. 34, no. 1, pp. 4369, 2008.

[23] M. S. Mauter and M. Elimelech, "Environmental applications of carbon-based nanomaterials," Environmental Science and Technology, vol. 42, no. 16, pp. 5843-5859, 2008.

[24] T. Masciangioli and W. X. Zhang, "Environmental technologies at the nanoscale," Environmental Science and Technology, vol. 37 , no. 5, 2003.

[25] R. Lal, "Promise and limitations of soils to minimize climate change," Journal of Soil and Water Conservation, vol. 63, no. 4, 2008.

[26] R. T. Pabalan and F. P. Bertetti, "Cation-exchange properties of natural zeolites," in Natural Zeolites: Occurrence, Properties, Applications, D. L. Bish and D. W. Ming, Eds., vol. 45, pp. 453-518, Mineralogical Society of America Reviews in Mineralogy and Geochemistry, Washington, DC, USA, 2001.

[27] F. A. Mumpton, "Using zeolites in agriculture," in Innovative Biological Technologies for Lesser Developed Countries, Congress of the United States, Office of Technology Assessment, Washington, DC, USA, 1985.

[28] J. L. Boettinger and D. W. Ming, "Zeolites," in Soil Mineralogy with Environmental Applications, J. B. Dixon and D. G. Schulze, Eds., SSSA Book Series 7, pp. 585-610, Soil Science Society of America, Madison, Wis, USA, 2002. 
[29] L. J. M. Githinji, J. H. Dane, and R. H. Walker, "Physical and hydraulic properties of inorganic amendments and modeling their effects on water movement in sand-based root zones," Irrigation Science, vol. 29, no. 1, pp. 65-77, 2011.

[30] G. R. Wehtje, J. N. Shaw, R. H. Walker, and W. Williams, "Bermudagrass growth in soil supplemented with inorganic amendments," HortScience, vol. 38, no. 4, pp. 613-617, 2003.

[31] A. M. Petrovic, "The potential of natural zeolite as a soil amendment," Golf Course Manage, vol. 58, no. 11, pp. 92-93, 1990.

[32] Z. T. Huang and A. M. Petrovic, "Physical properties of sand as affected by clinoptilolite zeolite particle size and quantity," Journal of Turfgrass Management, vol. 1, no. 1, pp. 1-15, 1995.

[33] Z. T. Huang and A. M. Petrovic, "Clinoptilolite zeolite effect on evapotranspiration rate and shoot growth rate of creeping bentgrass on sand base greens," Journal of Turfgrass Management, vol. 1, no. 4, pp. 1-9, 1996.

[34] Z. Lopez, A. S. Bawazir, B. Tanzy, and E. Adkins, "Using St. Cloud clinoptilolite zeolite as a wicking material to sustain riparian vegetation," in Proceedings of the 2008 Joint Meeting of The Geological Society of America, Soil Science Society of America, American Society of Agronomy, Crop Science Society of America, Gulf Coast Association of Geological Societies with the Gulf Coast Section of SEPM. Paper No. 546, 2008.

[35] Z. T. Huang and A. M. Petrovic, "Clinoptilolite zeolite influence on nitrate leaching and nitrogen use efficiency in simulated sand based golf greens," Journal of Environmental Quality, vol. 23, no. 6, pp. 1190-1194, 1994.

[36] L. E. Katz, D. N. Humphrey, P. T. Jankauskas, and F. A. Demascio, "Engineered soils for low-level radioactive waste disposal facilities: effects of additives on the adsorptive behavior and hydraulic conductivity of natural soils," Hazardous Waste and Hazardous Materials, vol. 13, no. 2, pp. 283306, 1996.

[37] H. Khan, A. Z. Khan, R. Khan, N. Matsue, and T. Henmi, "Influence of zeolite application on germination and seed quality of soybean grown on allophanic soil," Research Journal of Seed Science, vol. 2, no. 1, pp. 1-8, 2009.

[38] K. Torii, "Utilization of natural zeolites in Japan," in Natural Zeolites: Occurrence, Properties, Use, L. B. Sand and F. A. Mumpton, Eds., pp. 441-450, Pergamon Press, Elmsford, NY, USA, 1978.

[39] G. A. Mazur, G. K. Medvid, and T. I. Grigora, "Use of natural zeolites for increasing the fertility of light textured soils," Eurasian Soil Science, vol. 10, pp. 70-77, 1984.

[40] R. Liu and R. Lal, "A laboratory study on improvement of mine soil quality for re-vegetation through various amendments," in Proceedings of the ASA-CSSA-SSSA International Annual Meetings, Cincinnati, Ohio, USA, October 2012.

[41] J. A. Burger and C. E. Zipper, "How to restore forests on surface-mined land," Publication 460-123, Virginia Cooperative Extension (VCE), Stanardsville, Va, USA, 2011.

[42] T. S. Perrin, D. T. Drost, J. L. Boettinger, and J. M. Norton, "Ammonium-loaded clinoptilolite: a slow-release nitrogen fertilizer for sweet corn," Journal of Plant Nutrition, vol. 21, no. 3, pp. 515-530, 1998.

[43] M. D. Lewis, I. F. D. Moore, and K. L. Goldsberry, "Ammonium-exchanged clinoptilolite and granulated clinoptilolite with urea as nitrogen fertilizers," in Zeo-Agriculture: Use of Natural Zeolites in Agriculture and Aquaculture, W. G. Pond and F. A. Mumpton, Eds., pp. 105-111, Westview Press, Boulder, Colo, USA, 1984.
[44] K. A. Barbarick and H. J. Pirela, "Agronomic and horticultural uses of zeolites: a review," in Zeo-Agriculture: Use of $\mathrm{Na}$ tural Zeolites in Agriculture and Aquaculture, W. G. Pond and F. A. Mumpton, Eds., pp. 93-103, Westview Press, Boulder, Colo, USA, 1984.

[45] K. A. Williams and P. V. Nelson, "Using precharged zeolite as a source of potassium and phosphate in a soilless container medium during potted chrysanthemum production," Journal of the American Society for Horticultural Science, vol. 122, no. 5, pp. 703-708, 1997.

[46] J. L. Carlino, K. A. Williams, and E. R. Allen, "Evaluation of zeolite-based soilless root media for potted chrysanthemum production," HortTechnology, vol. 8, no. 3, pp. 373-378, 1998.

[47] T. M. Lai and D. D. Eberl, "Controlled and renewable release of phosphorous in soils from mixtures of phosphate rock and NH4-exchanged clinoptilolite," Zeolites, vol. 6, no. 2, pp. 129132, 1986.

[48] D. D. Eberl, K. A. Barbarick, and T. M. Lai, "Influence of NH4-exchanged clinoptilolite on nutrient concentrations in sorghum-sudangrass," in Natural Zeolites '93: Occurrence, Properties, Use, D. W. Ming and F. A. Mumpton, Eds., pp. 491-504, Int'l Comm Natural Zeolites, Brockport, NY, USA, 1995.

[49] E. R. Allen, L. R. Hossner, D. W. Ming, and D. L. Henninger, "Solubility and cation exchange in phosphate rock and saturated clinoptilolite mixtures," Soil Science Society of America Journal, vol. 57, no. 5, pp. 1368-1374, 1993.

[50] Z. L. He, V. C. Baligar, D. C. Martens, K. D. Ritchey, and M. Elrashidi, "Effect of byproduct, nitrogen fertilizer, and zeolite on phosphate rock dissolution and extractable phosphorus in acid soil," Plant and Soil, vol. 208, no. 2, pp. 199-207, 1999.

[51] M. C. Derosa, C. Monreal, M. Schnitzer, R. Walsh, and Y. Sultan, "Nanotechnology in fertilizers," Nature Nanotechnology, vol. 5, no. 2, p. 91, 2010.

[52] R. Liu and D. Zhao, "Reducing leachability and bioaccessibility of lead in soils using a new class of stabilized iron phosphate nanoparticles," Water Research, vol. 41, no. 12, pp. 2491-2502, 2007.

[53] R. Liu, "In-situ lead remediation in a shoot-range soil using stabilized apatite nanoparticles," in Proceedings of the 85th ACS Colloid and Surface Science Symposium, McGill University, Montreal, Canada, June 2011.

[54] R. Edwards, I. Rebedea, N. W. Lepp, and A. J. Lovell, "An investigation into the mechanism by which synthetic zeolites reduce labile metal concentrations in soils," Environmental Geochemistry and Health, vol. 21, no. 2, pp. 157-173, 1999.

[55] C. F. Lin, S. S. Lo, H. Y. Lin, and Y. Lee, "Stabilization of cadmium contaminated soils using synthesized zeolite," Journal of Hazardous Materials, vol. 60, no. 3, pp. 217-226, 1998.

[56] A. Shanableh and A. Kharabsheh, "Stabilization of Cd, Ni and $\mathrm{Pb}$ in soil using natural zeolite," Journal of Hazardous Materials, vol. 45, no. 2-3, pp. 207-217, 1996.

[57] A. Moirou, A. Xenidis, and I. Paspaliaris, "Stabilization Pb, $\mathrm{Zn}$, and Cd-contaminated soil by means of natural zeolite," Soil and Sediment Contamination, vol. 10, no. 3, pp. 251-267, 2001.

[58] C. Haidouti, "Inactivation of mercury in contaminated soils using natural zeolites," Science of the Total Environment, vol. 208, no. 1-2, pp. 105-109, 1997.

[59] A. Chlopecka and D. C. Adriano, "Mimicked in-situ stabilization of metals in a cropped soil: bioavailability and chemical form of zinc," Environmental Science and Technology, vol. 30, no. 11, pp. 3294-3303, 1996. 
[60] A. S. Knox, D. I. Kaplan, D. C. Adriano, T. G. Hinton, and M. D. Wilson, "Apatite and phillipsite as sequestering agents for metals and radionuclides," Journal of Environmental Quality, vol. 32, no. 2, pp. 515-525, 2003.

[61] M. R. Mahmoodabadi, "Experimental study on the effects of natural zeolite on lead toxicity, growth, nodulation, and chemical composition of soybean," Communications in Soil Science and Plant Analysis, vol. 41, no. 16, pp. 1896-1902, 2010.

[62] W. Geebelen, J. Vangronsveld, D. C. Adriano, R. Carleer, and H. Clijsters, "Amendment-induced immobilization of lead in a lead-spiked soil: evidence from phytotoxicity studies," Water, Air, and Soil Pollution, vol. 140, no. 1-4, pp. 261-277, 2002.

[63] E. Coppola, G. Battaglia, M. Bucci et al., "Remediation of $\mathrm{Cd}$ - and $\mathrm{Pb}$-polluted soil by treatment with organo-zeolite conditioner," Clays and Clay Minerals, vol. 51, no. 6, pp. 609615, 2003.

[64] K. Stead, Environmental implications of using the natural zeolite clinoptilolite for the remediation of sludge amended soils [Ph.D. thesis], University of Surrey, Surrey, UK, 2002.

[65] J. M. Bigham, R. W. Fitzpatrick, and D. G. Schulze, "Iron oxides," in Soil Mineralogy with Environmental Applications, J. B. Dixon and D. G. Schulze, Eds., pp. 323-366, Soil Science Society of America, Madison, Wis, USA, 2002.

[66] M. Hua, S. Zhang, B. Pan, W. Zhang, L. Lv, and Q. Zhang, "Heavy metal removal from water/wastewater by nanosized metal oxides: a review," Journal of Hazardous Materials, vol. 211-212, pp. 317-331, 2012.

[67] A. Xenidis, C. Stouraiti, and N. Papassiopi, "Stabilization of $\mathrm{Pb}$ and $\mathrm{As}$ in soils by applying combined treatment with phosphates and ferrous iron," Journal of Hazardous Materials, vol. 177, no. 1-3, pp. 929-937, 2010.

[68] J. Kumpiene, A. Lagerkvist, and C. Maurice, "Stabilization of $\mathrm{As}, \mathrm{Cr}, \mathrm{Cu}, \mathrm{Pb}$ and $\mathrm{Zn}$ in soil using amendments-a review," Waste Management, vol. 28, no. 1, pp. 215-225, 2008.

[69] USEPA, the Use of Soil Amendments for Remediation, Revitalization and Reuse. Solid Waste and Emergency Response (5203P) EPA 542-R-07-013, http://clu-in.org/download/ remed/epa-542-r-07-013.pdf, 2007.

[70] H. J. Shipley, K. E. Engates, and A. M. Guettner, "Study of iron oxide nanoparticles in soil for remediation of arsenic," Journal of Nanoparticle Research, vol. 13, no. 6, pp. 23872397, 2011.

[71] D. O'Carroll, B. Sleep, M. Krol, H. Boparai, and C. Kocur, "Nanoscale zero valent iron and bimetallic particles for contaminated site remediation," Advances in Water Resources. In press.

[72] J. D. Hu, Y. Zevi, X. M. Kou, J. Xiao, X. J. Wang, and Y. Jin, "Effect of dissolved organic matter on the stability of magnetite nanoparticles under different $\mathrm{pH}$ and ionic strength conditions," Science of the Total Environment, vol. 408, no. 16, pp. 3477-3489, 2010.

[73] Y. T. He, J. Wan, and T. Tokunaga, "Kinetic stability of hematite nanoparticles: the effect of particle sizes," Journal of Nanoparticle Research, vol. 10, no. 2, pp. 321-332, 2008.

[74] M. Baalousha, "Aggregation and disaggregation of iron oxide nanoparticles: influence of particle concentration, $\mathrm{pH}$ and natural organic matter," Science of the Total Environment, vol. 407, no. 6, pp. 2093-2101, 2009.

[75] Y. Hong, R. J. Honda, N. V. Myung, and S. L. Walker, “Transport of iron-based nanoparticles: role of magnetic properties," Environmental Science and Technology, vol. 43, no. 23, pp. 8834-8839, 2009.
[76] M. Baalousha, A. Manciulea, S. Cumberland, K. Kendall, and J. R. Lead, "Aggregation and surface properties of iron oxide nanoparticles: influence of $\mathrm{pH}$ and natural organic matter," Environmental Toxicology and Chemistry, vol. 27, no. 9, pp. 1875-1882, 2008.

[77] H. L. Karlsson, J. Gustafsson, P. Cronholm, and L. Möller, "Size-dependent toxicity of metal oxide particles-A comparison between nano- and micrometer size," Toxicology Letters, vol. 188, no. 2, pp. 112-118, 2009.

[78] M. Auffan, L. Decome, J. Rose et al., "In vitro interactions between DMSA-coated maghemite nanoparticles and human fibroblasts: a physicochemical and cyto-genotoxical study," Environmental Science and Technology, vol. 40, no. 14, pp. 4367-4373, 2006.

[79] L. K. Limbach, P. Wick, P. Manser, R. N. Grass, A. Bruinink, and W. J. Stark, "Exposure of engineered nanoparticles to human lung epithelial cells: influence of chemical composition and catalytic activity on oxidative stress," Environmental Science and Technology, vol. 41, no. 11, pp. 4158-4163, 2007.

[80] N. Sadeghiani, L. S. Barbosa, L. P. Silva, R. B. Azevedo, P. C. Morais, and Z. G. M. Lacava, "Genotoxicity and inflammatory investigation in mice treated with magnetite nanoparticles surface coated with polyaspartic acid," Journal of Magnetism and Magnetic Materials, vol. 289, pp. 466-468, 2005.

[81] W. X. Zhang, "Nanoscale iron particles for environmental remediation: an overview," Journal of Nanoparticle Research, vol. 5, no. 3-4, pp. 323-332, 2003.

[82] B. Cao, B. Ahmed, and H. Beyenal, "Immobilization of uranium in groundwater using biofilms," in Emerging Environmental Technologies, V. Shah, Ed., vol. 2, pp. 1-37, Springer, New York, NY, USA, 2010.

[83] A. Abdelouas, "Uranium mill tailings: geochemistry, mineralogy, and environmental impact," Elements, vol. 2, no. 6, pp. 335-341, 2006.

[84] S. Yan, B. Hua, Z. Bao, J. Yang, C. Liu, and B. Deng, "Uranium(VI) removal by nanoscale zerovalent iron in anoxic batch systems," Environmental Science and Technology, vol. 44, no. 20, pp. 7783-7789, 2010.

[85] J. N. Fiedor, W. D. Bostick, R. J. Jarabek, and J. Farrell, "Understanding the mechanism of uranium removal from groundwater by zero- valent iron using X-ray photoelectron spectroscopy," Environmental Science and Technology, vol. 32, no. 10 , pp. 1466-1473, 1998.

[86] R. A. Crane, M. Dickinson, I. C. Popescu, and T. B. Scott, "Magnetite and zero-valent iron nanoparticles for the remediation of uranium contaminated environmental water," Water Research, vol. 45, no. 9, pp. 2931-2942, 2011.

[87] M. Dickinson and T. B. Scott, "The application of zerovalent iron nanoparticles for the remediation of a uraniumcontaminated waste effluent," Journal of Hazardous Materials, vol. 178, no. 1-3, pp. 171-179, 2010.

[88] O. Riba, T. B. Scott, K. Vala Ragnarsdottir, and G. C. Allen, "Reaction mechanism of uranyl in the presence of zero-valent iron nanoparticles," Geochimica et Cosmochimica Acta, vol. 72, no. 16, pp. 4047-4057, 2008.

[89] D. V. Franco, L. M. Da Silva, and W. F. Jardim, "Reduction of hexavalent chromium in soil and ground water using zerovalent iron under batch and semi-batch conditions," Water, Air, and Soil Pollution, vol. 197, no. 1-4, pp. 49-60, 2009.

[90] Y. Xu and D. Zhao, "Reductive immobilization of chromate in water and soil using stabilized iron nanoparticles," Water Research, vol. 41, no. 10, pp. 2101-2108, 2007. 
[91] S. M. Ponder, J. G. Darab, and T. E. Mallouk, "Remediation of $\mathrm{Cr}(\mathrm{VI})$ and $\mathrm{Pb}(\mathrm{II})$ aqueous solutions using supported, nanoscale zero-valent iron," Environmental Science and Technology, vol. 34, no. 12, pp. 2564-2569, 2000.

[92] A. D. Lemly, "Environmental implications of excessive selenium: a review," Biomedical and Environmental Sciences, vol. 10, no. 4, pp. 415-435, 1997.

[93] C. L. Mackowiak and M. C. Amacher, "Soil sulfur amendments suppress selenium uptake by alfalfa and western wheatgrass," Journal of Environmental Quality, vol. 37, no. 3, pp. 772-779, 2008.

[94] S. T. Witte and L. A. Will, "Investigation of selenium sources associated with chronic selenosis in horses of western Iowa," Journal of Veterinary Diagnostic Investigation, vol. 5, no. 1, pp. 128-131, 1993.

[95] P. Thomas, J. Irvine, J. Lyster, and R. Beaulieu, "Radionuclides and trace metals in Canadian moose near uranium mines: Comparison of radiation doses and food chain transfer with cattle and caribou," Health Physics, vol. 88, no. 5, pp. 423-438, 2005.

[96] J. T. Olegario, N. Yee, M. Miller, J. Sczepaniak, and B. Manning, "Reduction of Se(VI) to Se(-II) by zerovalent iron nanoparticle suspensions," Journal of Nanoparticle Research, vol. 12, no. 6, pp. 2057-2068, 2010.

[97] L. Alidokht, A. R. Khataee, A. Reyhanitabar, and S. Oustan, "Cr(VI) Immobilization process in a Cr-spiked soil by zerovalent iron nanoparticles: optimization using response surface methodology," Clean-Soil, Air, Water, vol. 39, no. 7, pp. 633-640, 2011.

[98] X. Q. Li and W. X. Zhang, "Sequestration of metal cations with zerovalent iron nanoparticles: a study with high resolution x-ray photoelectron spectroscopy (HR-XPS)," Journal of Physical Chemistry C, vol. 111, no. 19, pp. 6939-6946, 2007.

[99] X. Q. Li and W. X. Zhang, "Iron nanoparticles: the core-shell structure and unique properties for $\mathrm{Ni}(\mathrm{II})$ sequestration," Langmuir, vol. 22, no. 10, pp. 4638-4642, 2006.

[100] S. R. Kanel, J. M. Greneche, and H. Choi, "Arsenic(V) removal from groundwater using nano scale zero-valent iron as a colloidal reactive barrier material," Environmental Science and Technology, vol. 40, no. 6, pp. 2045-2050, 2006.

[101] S. R. Kanel, B. Manning, L. Charlet, and H. Choi, "Removal of arsenic(III) from groundwater by nanoscale zero-valent iron," Environmental Science and Technology, vol. 39, no. 5, pp. 1291-1298, 2005.

[102] T. Watanabe, Y. Murata, T. Nakamura, Y. Sakai, and M. Osaki, "Effect of zero-valent iron application on cadmium uptake in rice plants grown in cadmium-contaminated soils," Journal of Plant Nutrition, vol. 32, no. 7, pp. 1164-1172, 2009.

[103] N. Saleh, H. Kim, T. Phenrat et al., "Ionic strength and composition affect the mobility of surface-modified $\mathrm{Fe} 0$ nanoparticles in water-saturated sand columns," Environmental Science \& Technology, vol. 42, no. 9, pp. 3349-3355, 2008.

[104] P. G. Tratnyek and R. L. Johnson, "Nanotechnologies for environmental cleanup," Nano Today, vol. 1, no. 2, pp. 4448, 2006.

[105] F. He and D. Zhao, "Preparation and characterization of a new class of starch-stabilized bimetallic nanoparticles for degradation of chlorinated hydrocarbons in water," Environmental Science and Technology, vol. 39, no. 9, pp. 3314-3320, 2005.

[106] F. He and D. Zhao, "Manipulating the size and dispersibility of zerovalent iron nanoparticles by use of carboxymethyl cellulose stabilizers," Environmental Science and Technology, vol. 41, no. 17, pp. 6216-6221, 2007.

[107] T. Phenrat, N. Saleh, K. Sirk, H. J. Kim, R. D. Tilton, and G. V. Lowry, "Stabilization of aqueous nanoscale zerovalent iron dispersions by anionic polyelectrolytes: adsorbed anionic polyelectrolyte layer properties and their effect on aggregation and sedimentation," Journal of Nanoparticle Research, vol. 10, no. 5, pp. 795-814, 2008.

[108] N. Sakulchaicharoen, D. M. O'Carroll, and J. E. Herrera, "Enhanced stability and dechlorination activity of presynthesis stabilized nanoscale FePd particles," Journal of Contaminant Hydrology, vol. 118, no. 3-4, pp. 117-127, 2010.

[109] B. C. Reinsch, B. Forsberg, R. L. Penn, C. S. Kim, and G. V. Lowry, "Chemical transformations during aging of zerovalent iron nanoparticles in the presence of common groundwater dissolved constituents," Environmental Science and Technology, vol. 44, no. 9, pp. 3455-3461, 2010.

[110] K. D. Grieger, A. Fjordbøge, N. B. Hartmann, E. Eriksson, P. L. Bjerg, and A. Baun, "Environmental benefits and risks of zero-valent iron nanoparticles (nZVI) for in situ remediation: risk mitigation or trade-off?" Journal of Contaminant Hydrology, vol. 118, no. 3-4, pp. 165-183, 2010.

[111] M. V. Ruby, A. Davis, and A. Nicholson, "In situ formation of lead phosphates in soils as a method to immobilize lead," Environmental Science Technology, vol. 28, no. 4, pp. 646-654, 1994.

[112] Q. Y. Ma, T. J. Logan, and S. J. Traina, "Lead immobilization from aqueous solutions and contaminated soils using phosphate rocks," Environmental Science and Technology, vol. 29, no. 4, pp. 1118-1126, 1995.

[113] S. Raicevic, T. Kaludjerovic-Radoicic, and A. I. Zouboulis, "In situ stabilization of toxic metals in polluted soils using phosphates: theoretical prediction and experimental verification," Journal of Hazardous Materials, vol. 117, no. 1, pp. 41-53, 2005.

[114] S. Raicevic, J. V. Wright, V. Veljkovic, and J. L. Conca, "Theoretical stability assessment of uranyl phosphates and apatites: selection of amendments for in situ remediation of uranium," Science of the Total Environment, vol. 355, no. 1-3, pp. 13-24, 2006.

[115] N. T. Basta and S. L. McGowen, "Evaluation of chemical immobilization treatments for reducing heavy metal transport in a smelter-contaminated soil," Environmental Pollution, vol. 127, no. 1, pp. 73-82, 2004.

[116] T. T. Eighmy, B. S. Crannell, L. G. Butler et al., "Heavy metal stabilization in municipal solid waste combustion dry scrubber residue using soluble phosphate," Environmental Science and Technology, vol. 31, no. 11, pp. 3330-3338, 1997.

[117] R. Stanforth and J. Qiu, "Effect of phosphate treatment on the solubility of lead in contaminated soil," Environmental Geology, vol. 41, no. 1-2, pp. 1-10, 2001.

[118] M. Peld, K. Tõnsuaadu, and V. Bender, "Sorption and desorption of $\mathrm{Cd}^{2+}$ and $\mathrm{Zn}^{2+}$ ions in apatite-aqueous systems," Environmental Science and Technology, vol. 38, no. 21, pp. 5626-5631, 2004.

[119] A. S. Knox, D. I. Kaplan, and M. H. Paller, "Phosphate sources and their suitability for remediation of contaminated soils," Science of the Total Environment, vol. 357, no. 1-3, pp. 271279, 2006.

[120] USEPA, US Environmental Protection Agency Region 10, 2001. Consensus plan for soil and sediment studies: Coeur d'Alene river soils and sediments bioavailability studies (URS 
DCN: 4162500.06161.05.a. EPA:16.2), pp. 1-16 http://yosemite.epa.gov/R10/CLEANUP.NSF/fb6a4e3291f5d28388256d140051048b/503bcd6aa1bd60a288256cce00070286/\$FILE/ soil_amend_consensus_final_022801.PDF, 2012.

[121] C. S. Reynolds and P. S. Davies, "Sources and bioavailability of phosphorus fractions in freshwaters: a British perspective," Biological Reviews of the Cambridge Philosophical Society, vol. 76, no. 1, pp. 27-64, 2001.

[122] J. N. Moore, W. H. Ficklin, and C. Johns, "Partitioning of arsenic and metals in reducing sulfidic sediments," Environmental Science and Technology, vol. 22, no. 4, pp. 432-437, 1988.

[123] G. T. Ankley, D. M. Di Toro, D. J. Hansen, and W. J. Berry, "Technical basis and proposal for deriving sediment quality criteria for metals," Environmental Toxicology and Chemistry, vol. 15, no. 12, pp. 2056-2066, 1996.

[124] J. Liu, K. T. Valsaraj, and R. D. Delaune, "Inhibition of mercury methylation by iron sulfides in an anoxic sediment," Environmental Engineering Science, vol. 26, no. 4, pp. 833840, 2009.

[125] J. M. Benoit, C. C. Gilmour, R. P. Mason, and A. Heyes, "Sulfide controls on mercury speciation and bioavailability to methylating bacteria in sediment pore waters," Environmental Science and Technology, vol. 33, no. 6, pp. 951-957, 1999.

[126] A. Drott, L. Lambertsson, E. Bjorn, and U. Skyllberg, "Importance of dissolved neutral mercury sulfides for methyl mercury production in contaminated sediments," Environmental Science and Technology, vol. 41, no. 7, pp. 2270-2276, 2007.

[127] Z. Xiong, F. He, D. Zhao, and M. O. Barnett, "Immobilization of mercury in sediment using stabilized iron sulfide nanoparticles," Water Research, vol. 43, no. 20, pp. 5171-5179, 2009.

[128] N. W. Revis, T. R. Osborne, G. Holdsworth, and C. Hadden, "Distribution of mercury species in soil from a mercurycontaminated site," Water, Air, and Soil Pollution, vol. 45, no. 1-2, pp. 105-113, 1989.

[129] D. Renock, T. Gallegos, S. Utsunomiya, K. Hayes, R. C. Ewing, and U. Becker, "Chemical and structural characterization of As immobilization by nanoparticles of mackinawite (FeSm)," Chemical Geology, vol. 268, no. 1-2, pp. 116-125, 2009.

[130] M. Wolthers, L. Charlet, C. H. van Der Weijden, P. R. van der Linde, and D. Rickard, "Arsenic mobility in the ambient sulfidic environment: sorption of $\operatorname{arsenic}(\mathrm{V})$ and arsenic(III) onto disordered mackinawite," Geochimica et Cosmochimica Acta, vol. 69, no. 14, pp. 3483-3492, 2005.

[131] T. J. Gallegos, P. H. Sung, and K. F. Hayes, "Spectroscopic investigation of the uptake of arsenite from solution by synthetic mackinawite," Environmental Science and Technology, vol. 41, no. 22, pp. 7781-7786, 2007.

[132] T. J. Gallegos, Y. S. Han, and K. F. Hayes, "Model predictions of realgar precipitation by reaction of As(III) with synthetic mackinawite under anoxic conditions," Environmental Science and Technology, vol. 42, no. 24, pp. 9338-9343, 2008.

[133] Y. Liu, J. Terry, and S. Jurisson, "Pertechnetate immobilization with amorphous iron sulfide," Radiochimica Acta, vol. 96, no. 12, pp. 823-833, 2008.

[134] R. R. Patterson, S. Fendorf, and M. Fendorf, "Reduction of hexavalent chromium by amorphous iron sulfide," Environmental Science and Technology, vol. 31, no. 7, pp. 2039-2044, 1997.
[135] B. Hua and B. Deng, "Reductive immobilization of uranium(VI) by amorphous iron sulfide," Environmental Science and Technology, vol. 42, no. 23, pp. 8703-8708, 2008.

[136] E. C. Butler and K. F. Hayes, "Effects of solution composition and $\mathrm{pH}$ on the reductive dechlorination of hexachloroethane by iron sulfide," Environmental Science and Technology, vol. 32, no. 9, pp. 1276-1284, 1998.

[137] E. C. Butler and K. F. Hayes, "Kinetics of the transformation of trichloroethylene and tetrachloroethylene by iron sulfide," Environmental Science and Technology, vol. 33, no. 12, pp. 2021-2027, 1999.

[138] E. C. Butler and K. F. Hayes, "Factors influencing rates and products in the transformation of trichloroethylene by iron sulfide and iron metal," Environmental Science and Technology, vol. 35, no. 19, pp. 3884-3891, 2001.

[139] X. Shi, K. Sun, L. P. Balogh, and J. R. Baker Jr., "Synthesis, characterization, and manipulation of dendrimer-stabilized iron sulfide nanoparticles," Nanotechnology, vol. 17, pp. 4554-4560, 2006.

[140] C. Blodau, "A review of acidity generation and consumption in acidic coal mine lakes and their watersheds," Science of the Total Environment, vol. 369, no. 1-3, pp. 307-332, 2006.

[141] H. Niu and Y. Cai, "Adsorption and concentration of organic contaminants by carbon nanotubes from environmental samples," in Advances in Nanotechnology and the Environment, J. Kim, Ed., pp. 79-136, Pan Stanford Publishing, Singapore, Singapore, 2012.

[142] G. P. Rao, C. Lu, and F. Su, "Sorption of divalent metal ions from aqueous solution by carbon nanotubes: a review," Separation and Purification Technology, vol. 58, no. 1, pp. 224-231, 2007.

[143] Y. H. Li, J. Ding, Z. Luan et al., "Competitive adsorption of $\mathrm{Pb} 2+, \mathrm{Cu} 2+$ and $\mathrm{Cd} 2+$ ions from aqueous solutions by multiwalled carbon nanotubes," Carbon, vol. 41, no. 14, pp. 2787-2792, 2003.

[144] C. Lu and C. Liu, "Removal of nickel(II) from aqueous solution by carbon nanotubes," Journal of Chemical Technology and Biotechnology, vol. 81, no. 12, pp. 1932-1940, 2006.

[145] H. Hyung, J. D. Fortner, J. B. Hughes, and J.-H. Kim, "Natural organic matter stabilizes carbon nanotubes in the aqueous phase," Environmental Science and Technology, vol. 41, no. 1, pp. 179-184, 2007.

[146] D. P. Jaisi and M. Elimelech, "Single-walled carbon nanotubes exhibit limited transport in soil columns," Environmental Science and Technology, vol. 43, no. 24, pp. 9161-9166, 2009.

[147] D. P. Jaisi, N. B. Saleh, R. E. Blake, and M. Elimelech, "Transport of single-walled carbon nanotubes in porous media: filtration mechanisms and reversibility," Environmental Science and Technology, vol. 42, no. 22, pp. 8317-8323, 2008.

[148] L. Jiang, L. Gao, and J. Sun, "Production of aqueous colloidal dispersions of carbon nanotubes," Journal of Colloid and Interface Science, vol. 260, no. 1, pp. 89-94, 2003.

[149] M. J. O’Connell, P. Boul, L. M. Ericson et al., "Reversible water-solubilization of single-walled carbon nanotubes by polymer wrapping," Chemical Physics Letters, vol. 342, no. 34, pp. 265-271, 2001.

[150] X. Zhou, L. Shu, H. Zhao et al., "Suspending multi-walled carbon nanotubes by humic acids from a peat soil," Environmental Science and Technology, vol. 46, no. 7, pp. 3891-3897, 2012.

[151] L. Xueying, D. M. O’Carroll, E. J. Petersen, H. Qingguo, and C. L. Anderson, "Mobility of multiwalled carbon nanotubes 
in porous media," Environmental Science and Technology, vol. 43, no. 21, pp. 8153-8158, 2009.

[152] D. B. Warheit, B. R. Laurence, K. L. Reed, D. H. Roach, G. A. M. Reynolds, and T. R. Webb, "Comparative pulmonary toxicity assessment of single-wall carbon nanotubes in rats," Toxicological Sciences, vol. 77, no. 1, pp. 117-125, 2004.

[153] C. W. Lam, J. T. James, R. McCluskey, and R. L. Hunter, "Pulmonary toxicity of single-wall carbon nanotubes in mice 7 and 90 days after intractracheal instillation," Toxicological Sciences, vol. 77, no. 1, pp. 126-134, 2004.

[154] G. Jia, H. Wang, L. Yan et al., "Cytotoxicity of carbon nanomaterials: single-wall nanotube, multi-wall nanotube, and fullerene," Environmental Science and Technology, vol. 39, no. 5, pp. 1378-1383, 2005.

[155] A. Magrez, S. Kasas, V. Salicio et al., "Cellular toxicity of carbon-based nanomaterials," Nano Letters, vol. 6, no. 6, pp. 1121-1125, 2006.

[156] X. Chen, U. C. Tam, J. L. Czlapinski et al., "Interfacing carbon nanotubes with living cells," Journal of the American Chemical Society, vol. 128, no. 19, pp. 6292-6293, 2006.

[157] X. Q. Li, D. G. Brown, and W. X. Zhang, "Stabilization of biosolids with nanoscale zero-valent iron (nZVI)," Journal of Nanoparticle Research, vol. 9, no. 2, pp. 233-243, 2007.

[158] N. G. Turan, "The effects of natural zeolite on salinity level of poultry litter compost," Bioresource Technology, vol. 99, no. 7, pp. 2097-2101, 2008.

[159] A. A. Zorpas, T. Constantinides, A. G. Vlyssides, I. Haralambous, and M. Loizidou, "Heavy metal uptake by natural zeolite and metals partitioning in sewage sludge compost," Bioresource Technology, vol. 72, no. 2, pp. 113-119, 2000.

[160] L. R. Nissen, N. W. Lepp, and R. Edwards, "Synthetic zeolites as amendments for sewage sludge-based compost," Chemosphere, vol. 41, no. 1-2, pp. 265-269, 2000.

[161] J. Villaseñor, L. Rodriguez, and F.J. Fernandez, "Composting domestic sewage sludge with natural zeolites in a rotary drum reactor," Bioresource Technology, vol. 102, no. 2, pp. 14471454, 2011.

[162] A. A. Zorpas and M. Loizidou, "Sawdust and natural zeolite as a bulking agent for improving quality of a composting product from anaerobically stabilized sewage sludge," Bioresource Technology, vol. 99, no. 16, pp. 7545-7552, 2008.

[163] A. A. Zorpas, I. Vassilis, M. Loizidou, and H. Grigoropoulou, "Particle size effects on uptake of heavy metals from sewage sludge compost using natural zeolite clinoptilolite," Journal of Colloid and Interface Science, vol. 250, no. 1, pp. 1-4, 2002.

[164] A. A. Zorpas, A. G. Vlyssides, and M. Loizidou, "Dewatered anaerobically-stabilized primary sewage sludge composting: metal leachability and uptake by natural clinoptilolite," Communications in Soil Science and Plant Analysis, vol. 30, no. 1112, pp. 1603-1613, 1999.

[165] V. P. Gadepalle, S. K. Ouki, R. Van Herwijnen, and T. Hutchings, "Immobilization of heavy metals in soil using natural and waste materials for vegetation establishment on contaminated sites," Soil and Sediment Contamination, vol. 16, no. 2, pp. 233-251, 2007.

[166] H. Andry, T. Yamamoto, and M. Inoue, "Influence of artificial zeolite and hydrated lime amendments on the erodibility of an acidic soil," Communications in Soil Science and Plant Analysis, vol. 40, no. 7-8, pp. 1053-1072, 2009.

[167] T. Yamamoto, A. Yuya, A. Satoh et al., "Application of artificial zeolite to combat soil erosion," in Proceedings of the American Society of Agricultural Engineers, Canadian Society for Engineering of Agricultural, Food and Biological System Annual International Meeting, Government Centre Ottawa, Ontario, Canada, August 2004.

[168] M. Zheng, A technology for enhanced control of erosion, sediment and metal leaching at disturbed land using polyacrylamide and magnetite nanoparticles [M.S. thesis], Auburn University, Auburn, Ala, USA, 2011.

[169] Z. S. Wang, M. T. Hung, and J. C. Liu, "Sludge conditioning by using alumina nanoparticles and polyelectrolyte," Water Science and Technology, vol. 56, no. 8, pp. 125-132, 2007.

[170] C. Ovenden and H. Xiao, "Flocculation behaviour and mechanisms of cationic inorganic microparticle/polymer systems," Colloids and Surfaces A, vol. 197, no. 1-3, pp. 225234, 2002.

[171] Z. Yan and Y. Deng, "Cationic microparticle based flocculation and retention systems," Chemical Engineering Journal, vol. 80, no. 1-3, pp. 31-36, 2000.

[172] T. H. Eyde, “Zeolites,” Minerals Engineering, vol. 62, p. 86, 2010.

[173] X. Q. Li, D. W. Elliott, and W. X. Zhang, "Zero-valent iron nanoparticles for abatement of environmental pollutants: materials and engineering aspects," Critical Reviews in Solid State and Materials Sciences, vol. 31, no. 4, pp. 111-122, 2006.

[174] Carbon nanotube, http://en.wikipedia.org/wiki/Carbon_nanotube, 2012. 

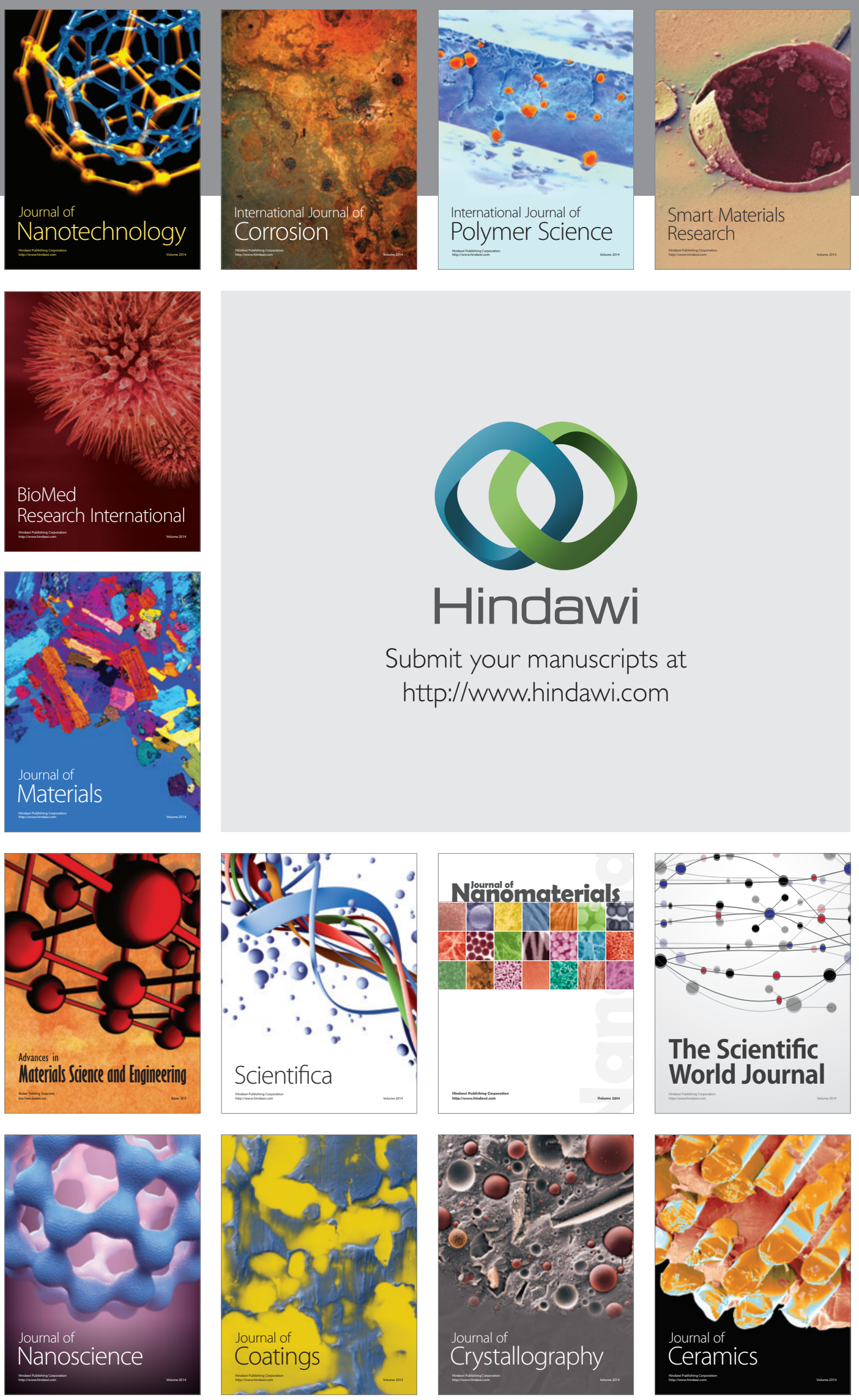

The Scientific World Journal

Submit your manuscripts at

http://www.hindawi.com

\section{World Journal}

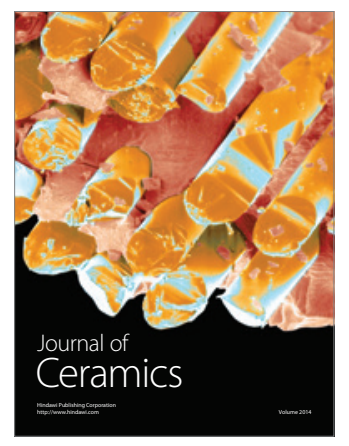

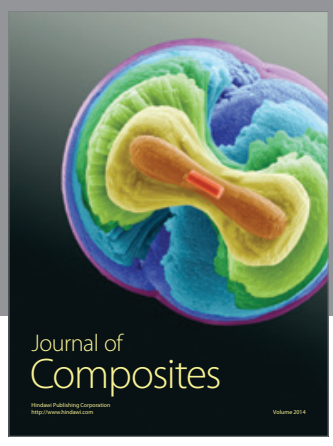
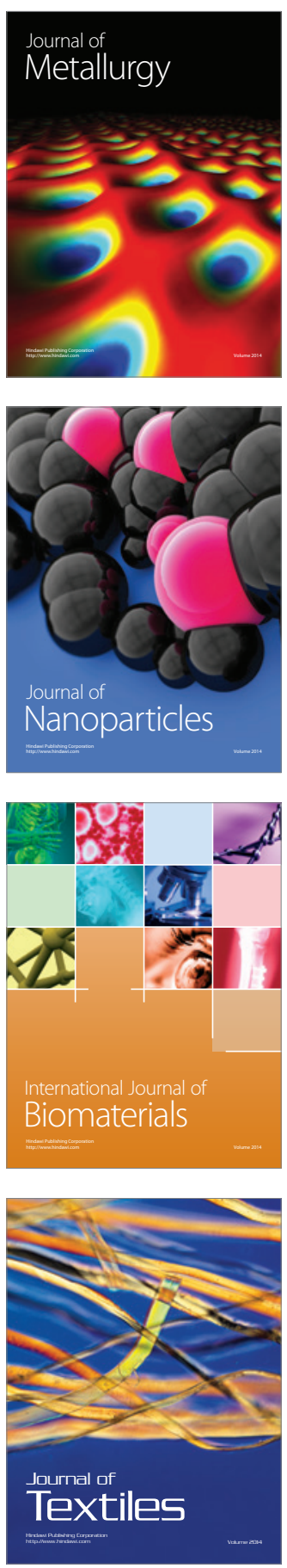